\title{
Exploring the effect of ICT and tourism on economic growth: a study of Israel
}

\author{
Ronald Ravinesh Kumar ${ }^{1,2}$ - Peter Josef Stauvermann ${ }^{3}$ • \\ Nikeel Kumar ${ }^{4}$ Syed Jawad Hussain Shahzad ${ }^{5}$
}

Received: 22 June 2017/ Accepted: 5 January 2018

(C) Springer Science+Business Media, LLC, part of Springer Nature 2018

\begin{abstract}
In this paper, we explore the impact of information and communications technology (ICT) and tourism on per worker output over the period 1960-2016 by using an augmented Solow (Quart J Econ 70(1): 65-94, 1956) framework estimated through the autoregressive distributed lag procedure for cointegration (Pesaran et al. in J Appl Econ 16(3):289-326, 2001). The results show that mobile cellular subscriptions (measure of ICT pervasiveness) and visitor arrivals as a percent of workers (measure of tourism) are cointegrated and positive, however, only ICT is statistically significant in the long-run. The long-run elasticity coefficient of ICT and tourism is 0.03 and 0.05 , respectively. We note a unidirectional causality from ICT to output per worker, from tourism to output per worker, from capital per worker to tourism, and from ICT to tourism. From the results, we emphasize that
\end{abstract}

Ronald Ravinesh Kumar

ronald.ravinesh.kumar@tdt.edu.vn

Peter Josef Stauvermann

pstauvermann@t-online.de; pjsta@changwon.ac.kr

Nikeel Kumar

S11085861@student.usp.ac.fj

Syed Jawad Hussain Shahzad

j.syed@montpellier-bs.com

1 Informetrics Research Group, Ton Duc Thang University, Ho Chi Minh City, Vietnam

2 Faculty of Social Sciences and Humanities, Ton Duc Thang University, Ho Chi Minh City, Vietnam

3 Department of Global Business and Economics, Changwon National University, Gyeongnam, 9 Sarim Dong, Changwon 641-773, Republic of Korea (South Korea)

4 School of Economics, Faculty of Business and Economics, University of the South Pacific, Suva, Fiji

5 Montpellier Business School, 2300 Avenue des Moulins, 34080 Montpellier, Montpellier, France 
focusing on technology advancement and tourism expansion will provide the necessary support for economic growth in the country.

Keywords ICT · Tourism · ARDL bounds · Granger causality · Israel

\section{Introduction}

Israel, a member of the Organisation for Economic Co-operation and Development (OECD), is a relatively advanced economy and ranked nineteenth in 2013 by the United Nation Human Development Index. The country is located at the eastern edge of the Mediterranean Sea, has a population of 8,547,100 (2016), and a per capita income of PPP \$32,613 (2016). Israel is considered a global leader in groundbreaking research in a number of areas including solar energy, water conservation, geothermal energy, software development and communications technology, and life sciences.

Moreover, Israel is praised to have a strong record of technological innovation and tourism attractions. Israel's geography provides a number of significant tourist products. These include a desert in the south, ski slopes in the north, historical sites, a diversity of religious sites such as Jerusalem, the Dead Sea (the lowest place on earth), and Tel Aviv (Israel's modern day capital). Religion, archaeology, heritage and ecotourism are important parts of the tourism industry (Singh and Krakover 2013). While Israel's security problems have affected the industry, it has remained relatively resilient. In 2005, total visitor arrivals were 1,903,000 and the figure increased by $44.2 \%$ in 2013 to $2,962,000$. The major source countries for tourists are the U.S.A., Russia, France, the U.K., Germany, Italy, Poland, the Netherlands, India, South Korea, Australia, and Brazil.

Unfortunately, Israel continues to face high cost as a result of intermittent conflicts. The country has been under constant military and terrorist threats since 1948 as a result of the civil war between the Jewish and Palestinian Arab populations. While the latter were supported by the neighbouring Arabic countries, the former was backed financially by the US and politically by the Soviet Union at that time. The first Israeli-Arab war in 1948/49 resulted in, among other things, the expulsion and flight of some 700,000 Palestinians from Israel to the neighbouring countries where they became refugees. The ongoing Israel-Palestinian conflict has created a history of consecutive wars, mutual terror and retaliation attacks. ${ }^{1}$ The key players in this conflict are Israel Defence Forces (IDF) and Mossad secret service on one side, and the Fatah-military arm of the Palestinian Liberation Organization

\footnotetext{
1 The following is a list of the important conflicts: reprisal operations (1950-1960) executed by Israel, Suez crisis (1956), Six-Day War (1967), Yom-Kippur War (1973), Palestinian insurgency in the SouthLebanon (1971-1982), Operation Litani (1978), first Lebanon War (1982), South Lebanon conflict (1982-2000), first Intifada (1987-1993), second Intifada (2000-2005), second Lebanon War (2006), Gaza War (2008/2009), operation Pillar of Defense (2012), operation Protective Edge (2014). Additionally, both sides have used asymmetric battle techniques such as bomb attacks, suicide attacks, assaults on civilians, hijacking, kidnapping, and murder.
} 
(PLO), the Hamas (Islamic Resistance Movement since 1988) and the military forces of Arabic countries, on the other. Both sides have repeatedly violated the UN resolutions, human rights and international laws. While Israel was initially internationally isolated, this has been largely overcome through political and financial support from countries such as the USA, France, and Germany. Although in 1995 the Gaza strip and West-Bank gained some autonomy, the ongoing violent conflict continues to create an economic burden for the civilians.

Amidst these developments, we examine the impact of ICT and tourism on the economic growth of Israel. In Fig. 1 we present the historical trends of mobile cellular subscription (\% population), and the uptake of internet, telephones and broadband. However, as noted from Fig. 2, the trends in tourism indicators, visitor arrivals as a percent of empolyment and tourism receipts as a percent of GDP, show an overall decline. We note that mobile cellular technology is the leading subssector of $\mathrm{ICT}^{2}$ followed by internet and fixed broadband technology. Therefore, we use mobile cellular subscription to proxy for ICT.

Israel has considerable advantages in ICT and tourism, however in terms of country-specific and sectoral studies viz. economic growth, studies on Israel has not been forthcoming. In what follows, we examine the short-run and long-run effects of ICT and tourism (measured by visitor arrivals) on per worker income using the augmented Solow (1956) framework and the ARDL bounds approach. Additionally, we account for structural breaks using relatively recent and robust methods capable of identifying multiple breaks within the sample. In summary, the following results are underscored: (a) ICT, tourism and output are cointegrated; (b) ICT is positive and statistically significant in the long-run; (c) tourism, although positive is significant in the short-run only; (d) the structural breaks have a positive influence on output per worker; and (e) the causality nexus shows a unidirectional causality from ICT to output per worker, and from tourism to output per worker thus confirming technology-led growth (Tech-LG) and tourism-led growth (TLH), respectively. The study therefore contributes to the literature on sector-based and country-specific growth studies by underscoring the role of ICT and tourism in Israel. In the remaining sections, we present the literature, modelling strategies and estimation techniques, empirical results, and conclusion.

\section{Literature review}

\subsection{ICT and economic growth}

Since ICT is a general purpose technology (GPT), its features coincide with other GPT's like electricity (Jovanovic and Rousseau 2005) or the steam engine (David 1990). In general, a GPT has three features: (a) it is widely applicable affecting most sectors; (b) it has innovational complementarities, which lead to a reduction of costs

\footnotetext{
${ }^{2}$ ICT refers to information and communication technology and can refer to different types of technology or Internet of Things (IoT). For our purpose, we restrict the definition to mobile cellular, internet, broadband and telecommunications (Kumar et al. 2016 and the references therein).
} 


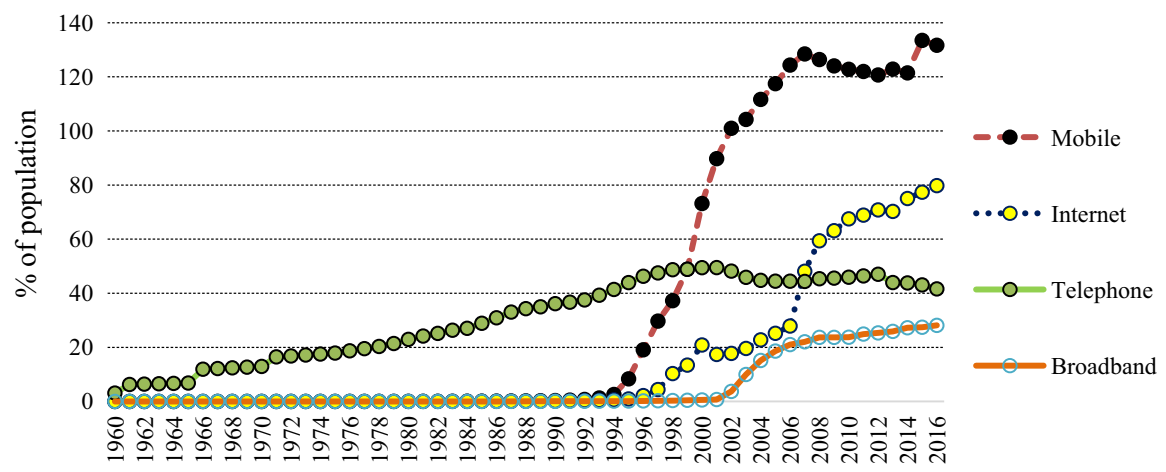

Fig. 1 Trends in ICT indicators. Source: World Bank (2017) and authors' own estimation

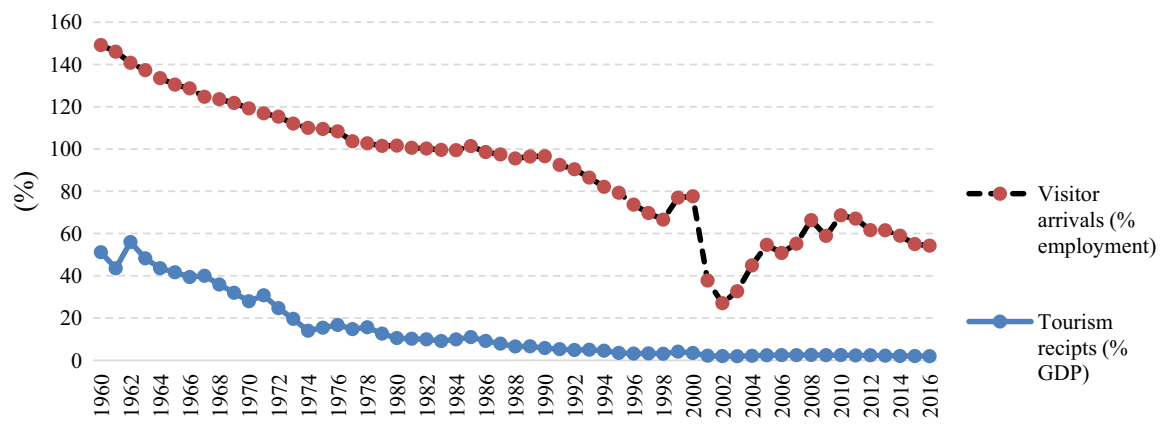

Fig. 2 Visitor arrivals and tourism receipts. Source: World Bank (2017) and authors' own estimation

of its users over time; and (c) it has technological complementarities, which stimulate new designs or re-designs of products and processes. ICT has these features: (a) almost all firms use some form of ICT; (b) ICT has reduced communication costs dramatically; and (c) ICT stimulates innovation in the context of 'internet of things' or artificial intelligence. Although, the growth effects caused by a GPT generally are unevenly distributed over time (Bresnahan and Trajtenberg 1995; Helpman and Trajtenberg 1998a, b; Aghion and Howitt 1998), the benefits are being realized in various ways (Helpman and Trajtenberg 1998a).

The growth effects caused by a GPT and particularly ICT can be divided into direct effects and indirect effects. The direct effects of ICT are related to the production of ICT products, which can be differentiated in the production of software and hardware. The indirect effects are related to the growth effects induced by the application of ICT products. The application of ICT technology reduces the communication costs directly and may reduce production costs through evolvement of new opportunities to improve production processes. Additionally, the consumers are affected by using and consuming ICT products, which may lead to changing consumer behaviour and to new growth opportunities (for example home offices). Also, by generating, storing and transmitting data, ICT technologies reduce market failures caused by information asymmetries. This argument holds for consumers and 
firms using ICT. Thus, ICT increases the efficiency of markets which should be reflected by increased growth. The indirect effects, which arises from horizontal and vertical spill-overs (Bresnahan and Trajtenberg 1995), cannot be realized immediately because it takes time for employees to get adjusted with evolving ICT, and to exploit all the opportunities offered by ICT. Therefore productivity gains from ICT is hardly possible in the short run-the latter explains the Solow-paradox. Because of the different channels through which ICT can influence growth, it is a complex task to properly define a unique indicator to measure the effect of ICT on growth and productivity.

Technology, defined as application of scientific knowledge for practical purposes, supports productivity and growth enhancement (Solow 1956; Romer 1986, 1990), lowers cost of production by streamlining of supply chain processes, and by providing access to information in decision making and creation of quality products at competitive prices (Cronin et al. 1991; Norton 1992; Madden and Savage 1998; Nadiri and Nandi 1999; Porter 2001; Jorgenson 2001; Stiroh 2002; Buhalis and Law 2008; Inklaar et al. 2008; Jorgenson and Vu 2011), A persistent effect of ICT on growth results, if the growth of the total factor productivity (TFP), which is a metric measuring the contribution of output beyond mere input usage (Hulten 2001; Comin et al. 2008; Demeter et al. 2011; Chou et al. 2014) is positively affected. In general, TFP represents the combination of technological progress, innovative production methods and other value improving features in production chains.

A summary of studies considering the Tech-LG is presented in Table 1. A few noteworthy observations are in order: (a) results on magnitudes and causality differ due to the differences in the method of analysis, sample size and/or ICT indicator; and (b) the common indicators of ICT are telephone lines per capita, telecommunications investments, broadband penetration, ICT-density (number of fixed-line and mobile phone subscribers per 100 inhabitants), computer hardware and software, and cellular density.

Earlier studies on Tech-LEG mainly focussed on the United States of America (USA). Cronin et al. (1991) consider the sample from 1958 to 188 and note a bidirectional causality. Colecchia and Schreyer (2002), and Daveri (2002) highlight the rise of the contribution of ICT capital to output growth in USA, and several European Union (EU) and OECD countries during the 1990s. Other studies on USA with similar findings include: Jorgenson and Stiroh (2000), Jorgenson (2001), and Oliner and Sichel (2000), Strobel (2016) and Jorgenson et al. (2016). In terms of the magnitude effects, Martínez et al. (2010) use a dynamic general equilibrium approach, with three ICT assets and three non-ICT assets as inputs, to examine the contribution of ICT on the growth of labour productivity between 1980 and 2014 . Their results showed that about a quarter of total productivity growth was due to the hardware equipment's and ICT-specific technological change accounted for $35 \%$ of the productivity growth.

Several studies use panel analysis and confirm the Tech-LG. For instance, Hardy (1980) considers 60 countries over the period 1968-1976 and finds strong evidence that telephones contribute to economic development. Madden and Savage (1998) examine a sample of 27 central and eastern European (CEE) countries over the 


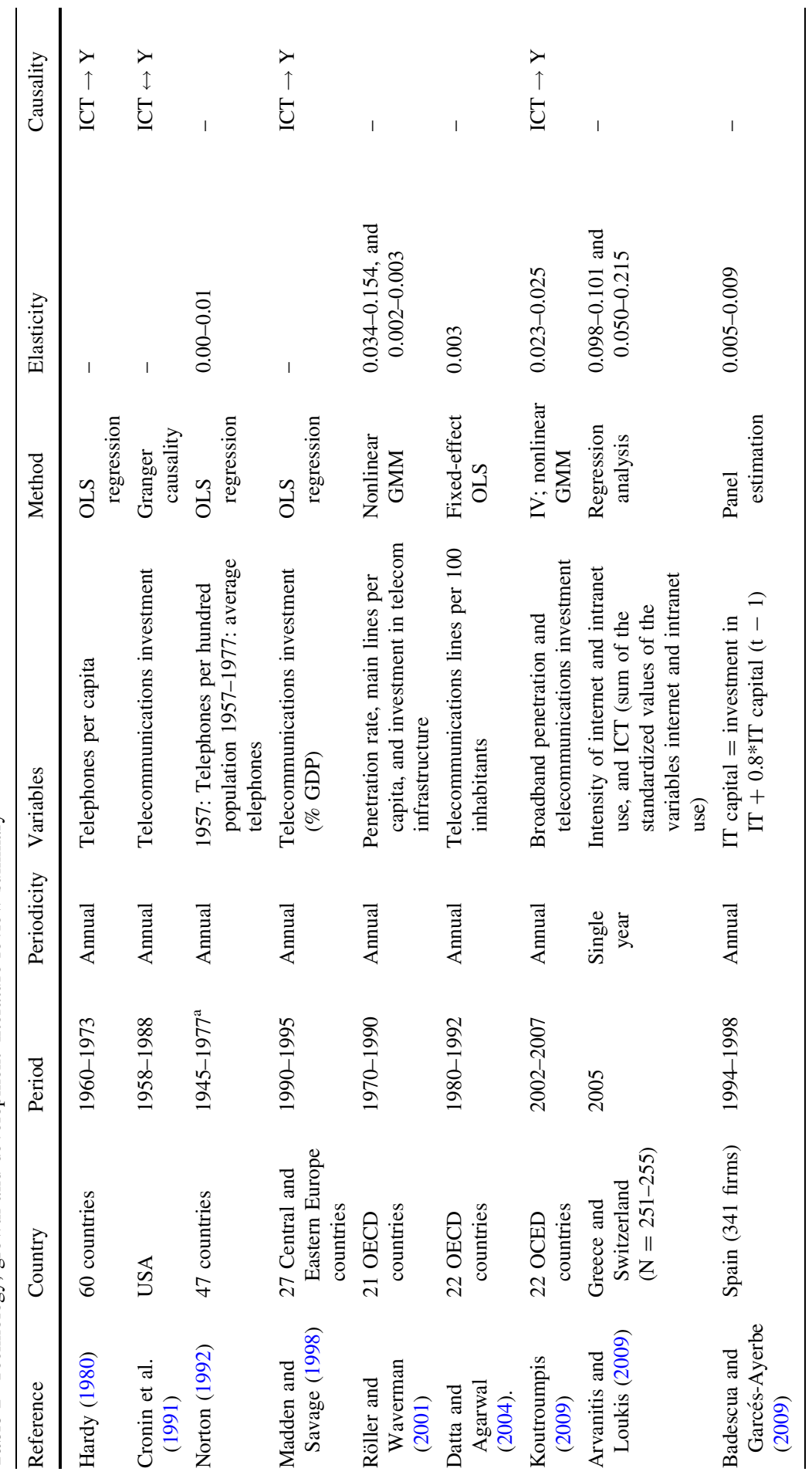




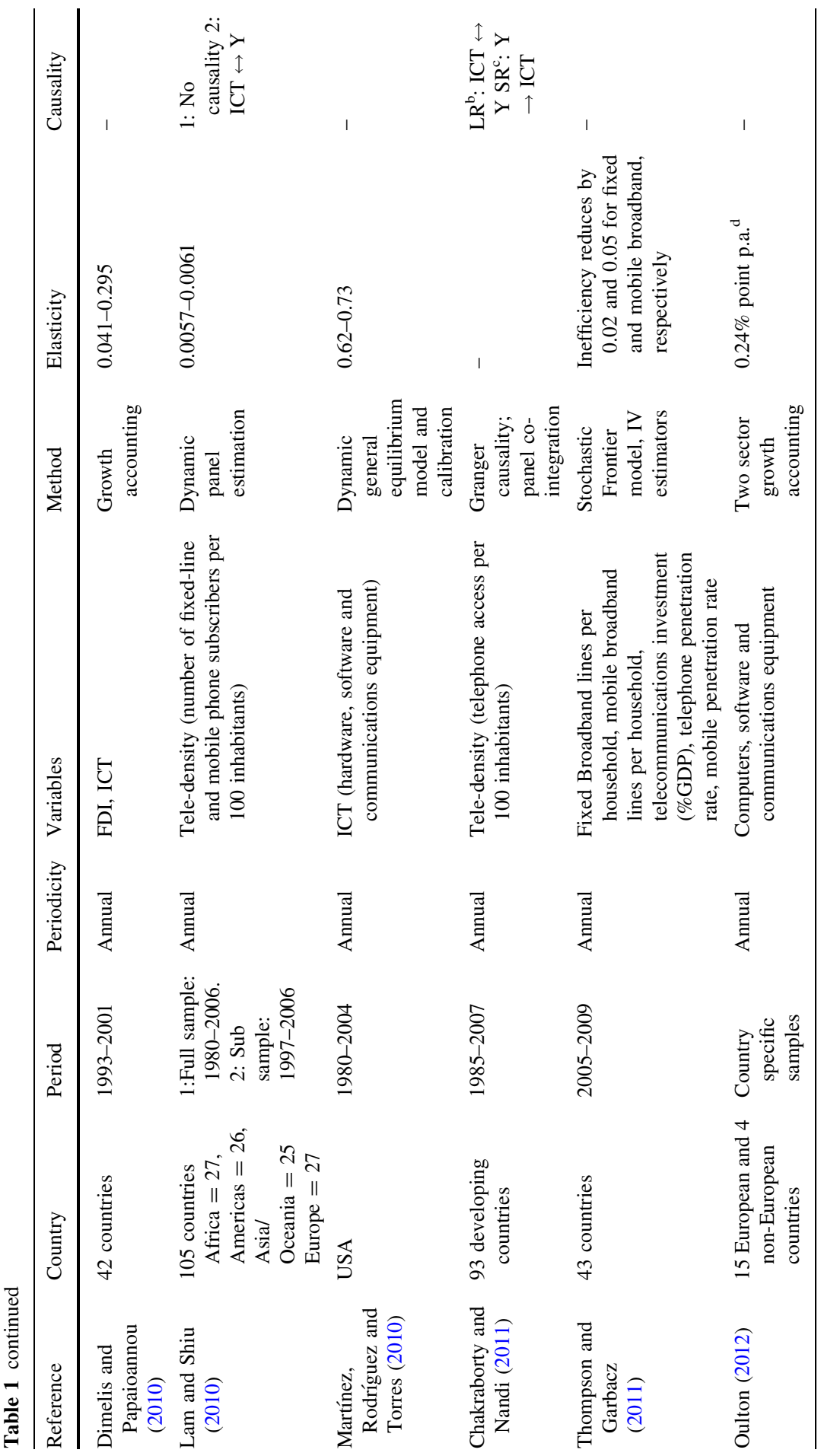




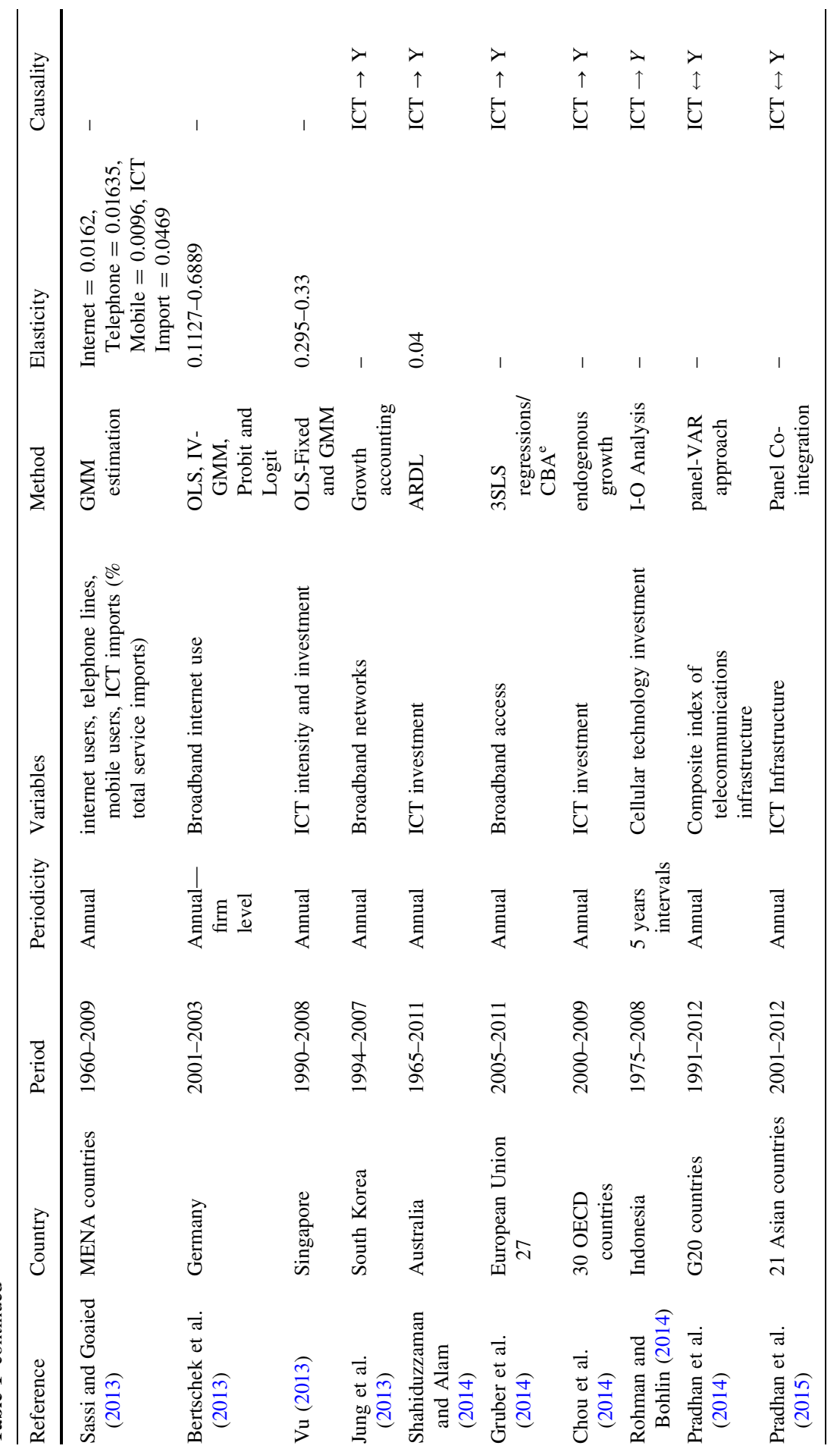




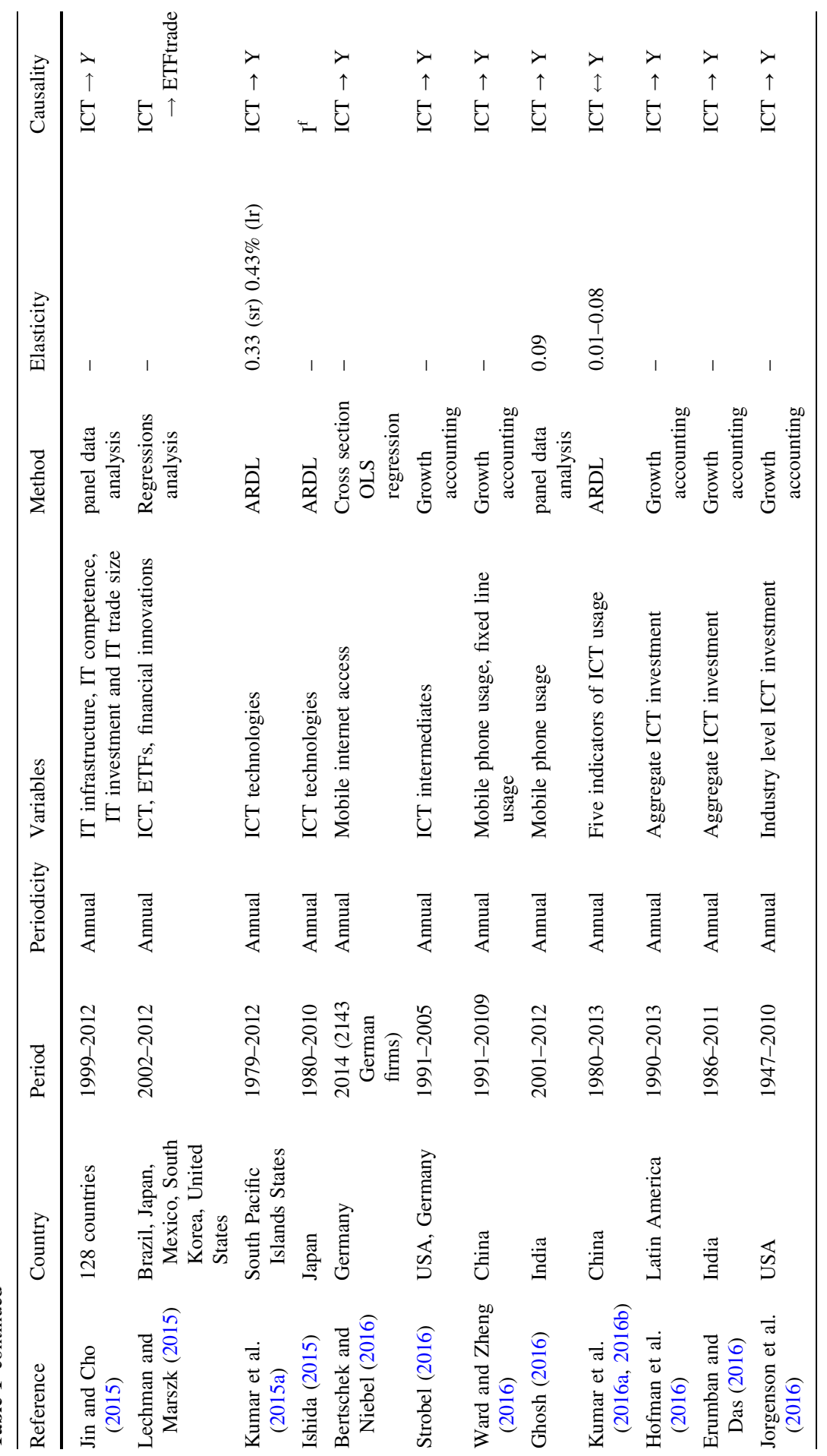




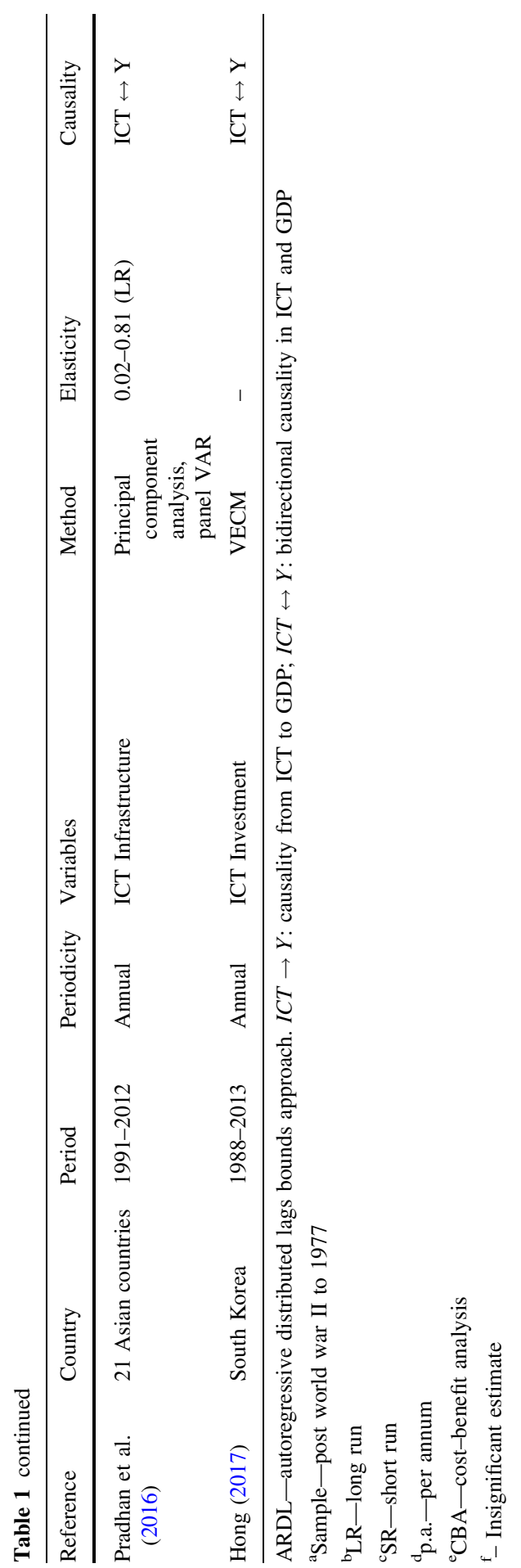


period 1990-1995, and find a positive relationship between investment in telecommunication infrastructure and economic growth. Similarly, Röller and Waverman (2001) consider 21 OECD countries over a 20-year period (1970-1990) and find a positive causal relationship between investment in telecommunication infrastructure and subsequent economic performance. Thompson and Garbacz (2011) consider a panel of 93 countries for the period 1995-2003 and find that penetration rates of telecommunication services improve the efficiency of production worldwide and particularly in some subsets of low income countries.

Other studies arriving at similar conclusion are: Jorgenson (2003) for the G-7 economies (Canada, France, Germany, Italy, Japan, the United Kingdom (UK), and the US), Jorgenson and $\mathrm{Vu}$ (2007) for 110 countries including US, and Venturini (2009) for USA and 15 EU countries. Seo et al. (2009) analyse a panel of 29 countries in the 1990s and conclude that ICT investment has a positive effect on GDP growth. Koutroumpis (2009) applies the model introduced by Röller and Waverman (2001) to 22 OECD countries over the period 2002-2007 and finds that broadband penetration (a proxy for ICT) has a positive causal link with economic growth in the presence of critical mass and infrastructure. Gruber and Koutroumpis (2010) use the data from 192 countries for the period 1990-2007 and find a significant effect of mobile telecommunications diffusion on GDP and productivity growth. $\mathrm{Vu}$ (2011) investigates the effect of ICT on growth for a sample of 102 countries for the period 1996-2005 and find inter alia: (a) a substantial improvement of growth in the sample period relative to previous years; (b) a statistically significant relationship between growth and ICT; and (c) penetration of personal computers, mobile phones, and internet users have a significant causal effect on growth. However there are a number of studies which find an inconclusive relationship. Dewan and Kraemer (2000), who examine 36 countries over the period 1985-1993 find returns from capital investments in ICT, although positive and significant for developed countries, were not statistically significant for developing countries. Pohjola (2002) examines a sample of 43 countries over the period 1985-1999 and finds no statistically significant correlation between ICT investment and economic growth.

Some country-specific studies emphasising the potential of ICT in promoting economic growth are: Oulton (2002) for the UK; Jalava and Pohjola (2002, 2008) for Finland; Daveri (2002) for the EU economies; Jorgenson and Motohashi (2005) for Japan; Kuppusamy et al. (2009) for Malaysia; Kumar (2011) for Nepal, Kumar and Kumar (2012) for Fiji; Kumar (2012) for Sub-Saharan Africa (SSA); Kumar (2013) for the Philippines; Kumar (2014a) for Vietnam ${ }^{3}$; Kumar et al. (2015a) for small Pacific island states; and Kumar et al. (2016a, b) for China. Vu (2013) examines the impact of ICT on the economic growth of Singapore over the periods 1990-2008 and estimates that ICT contributed about 1\% point to Singapore's GDP.

\footnotetext{
${ }^{3}$ However in another study Kumar and Vu (2014) find an absence of any causality between ICT and economic growth in Vietnam. This may be due their use of internet users (\% of population) as a measure of ICT, which differs from Kumar's (2014a, b) study which uses telecommunication lines (\% of population) as an indicator of ICT. In this study mobile cellular subscription are used as a measure to examine the impact of ICT on growth (c.f. Kumar et al. 2015b).
} 
Further, the Tech-LG hypothesis has been examined at firm and industry levels. For instance Lehr and Lichtenberg (1999) examine firms in service industries in Canada and find that personal computers made a positive contribution to productivity growth. Stiroh (2002) investigates some 57 major US industries and finds a strong link between ICT and productivity. Similarly, Brynjolfsson and Hitt (2003) find that firms investing in computer technology were able to increase productivity. O'Mahony and Vecchi (2005) use pooled data at the industry level for the US and the UK and find a positive effect of ICT on output growth and that the returns of ICT capital exceeds the returns of non-ICT assets.

ICT supports TFP growth through multiple channels. Investment in ICT has a direct output effect, a subsequent productivity effect, is a precursor for future innovation, can involve network externalities and knowledge spillovers (Becchetti and Adriani 2005). According to Reynolds and Samuels (2004) and Galperin (2005) the developments in ICT helps to reduce the communication and production costs, pave the way to improved production methods.

Additionally, Jorgenson (2001) and Strobel (2016) state that ICT development creates increasing returns to scale. While van Biesebroeck (2003) finds no evidence for ICT-led productivity enhancements in Brazilian firms, Kasahar and Rodrique (2008) conclude that the import of ICT inputs has increased the firm level productivity in Indonesia and Chile.

The ICT revolution (post 1980's) led to the creation of the new economy creating new, profitable business ventures, new jobs, new skills, innovative entrepreneurship and governance models (Arora and Athereye 2002). Given that ICT operates in the backdrop, it promotes further economic activity through other means such as supporting financial innovation, integration and intermediation (Lechman and Marszk 2015), transportation and logistics (Perego et al. 2011) and education (Pelgrum 2001). Moreover, at the aggregate level, most countries benefit from a leap-frog type cellular innovation which makes penetration costs of ICT relatively low and hence helps promote technical diffusion (Rohman and Bohlin 2014).

Despite its many advantages, two central complications in the Tech-LG proposition are accessibility and diffusion. Production of such technologies is restricted mostly to developed economies such as the USA or Japan where research and development is more profound. In these economies, the production of ICT would count as both a part of its direct real output as well as future productivity and external effects. Shih and Chang (2009) identify four international segments of technical diffusion, the leading countries actively engaging in $R \& D$ providing technological progress (e.g. the US, Germany, China, the Netherlands, Sweden); an intermediary segment that diffuses this knowledge (e.g. Canada, Belgium, Spain, Singapore, Austria); a third group that primarily exports this technological knowledge (Ireland, Brazil, Israel, Malaysia, Mexico, the Czech Republic); and a consumer group who absorbs technological knowledge without reciprocal exportation (Greece, Iceland, Indonesia, Lithuania, Malta). Next, we present the literature of the role of tourism on economic growth and development.

Whilst we note that there is no study specific to Israel and addressing the question of the extent to which ICT support the economic growth of the country, on a broader scale, a study by Dimelis and Papaioannou (2010) consider 42 developed and 
developing countries which include Israel. The authors find a positive association between productivity growth and ICT. However, for specific policy levers in economic planning and restructuring of the state, it is important that a countryspecific study is done. Thus, in this study, we do just that, and by underscoring the two sectors in Israel, we aim to modestly contribute to the respective literature on Tech-LG and TLG.

\subsection{Tourism and economic growth}

The literature on tourism and economic development dates back, at least to the pioneering work of Sheldon (1997) which paved the way for a plethora of studies to emerge. Among these include Durbarry (2004) who explores the impact of tourism receipts (a proxy for tourism) on Mauritius using real gross domestic investment (as a proxy for investment), secondary school enrolment (as a proxy for human capital), and disaggregated exports such as sugar, manufactured exports. Durbarry finds that tourism contributed about $0.8 \%$ to growth in the long-run. Nowak et al. (2007) consider the Spanish economy and show that tourism exports have a growth enhancing effect when income from tourism are used to finance imports of capital goods. Lee and Chang (2008) apply a heterogeneous panel co integration technique on a sample from OECD and non-OECD countries, and find that tourism has a greater impact on GDP in the non-OECD countries. Brida et al. (2008) examine the causal relationships among tourism expenditure, real exchange rates and economic growth based on quarterly data for Mexico and the Johansen cointegration technique. Their results show unidirectional causation from tourism to real GDP, this confirming the tourism-led growth (TLG) proposition. Fayissa et al. (2008) use a panel of 42 African countries within the conventional neoclassical framework to explore the potential contributions of tourism to growth. Their results show that tourism receipts contributed to the current level of output and economic growth of the African countries.

Holzner (2010) considers 134 countries to explore the 'Dutch disease' effect of tourism. ${ }^{4}$ He does not find any indication for the occurrence of a Dutch (beach) disease effect and instead concludes that tourism dependent countries benefit from higher economic growth as a result of tourism. Seetanah (2011) uses a panel of 19 island economies and the generalized method of moments (GMM) technique over the period 1990-2007 within the conventional augmented Solow growth model to examine the contribution of tourism to growth. He notes that tourism significantly contributes to economic growth and confirms a bidirectional causality between tourism and growth. Seetanah et al. (2011) explore 40 African countries over the period 1990-2006. They report, inter alia, a bi-causal and reinforcing relationship between tourism and output.

Kumar and Kumar (2012) consider Fiji, a small island economy in the Pacific. They examine the role of tourism and technology using the autoregressive distributed lag (ARDL) model within the augmented Solow framework. Their

\footnotetext{
${ }^{4}$ Dutch disease refers to the increase in the demand for domestic currency leading to appreciation of the currency and loss of competitiveness in the international market.
} 
results show tourism contributes $0.23 \%$ in the long-run and $0.19 \%$ in the short-run. Kumar and Kumar (2013) however reports a slightly lower contribution of tourism $(0.12 \%$ in the long-run) when additional drivers such as urbanization and ICT are included, where the latter have higher effects on growth. Chang et al. (2012) use an instrument variable estimation in a panel threshold model to investigate the importance of tourism specialization in economic development of 159 countries and find a positive relationship between growth and tourism. Kumar (2014b) considers the Kenyan economy and examines the role of tourism and remittances. He notes that only tourism has a positive and significant effect in the long-run.

On the other hand, there are a few studies which find tourism has no effect on economic growth. Among these include Oh (2005) who examines the causal relationship for the Korean economy using the Engle and Granger two-stage approach and a bivariate Vector Auto Regression (VAR) model. He finds there is no long-run equilibrium relationship between tourism and output, and only a unidirectional causality from output to tourism. Similarly, Katircioglu (2009) use the ARDL bounds test and Johansen approach to cointegration on data from Turkey. He finds no evidence of a cointegration between international tourism and economic growth.

Table 2 presents selected studies with magnitude effects and direction of causality viz. tourism and growth.

Upon reviewing the literature, it is clear that most of the studies underscore the momentous role of ICT and tourism in propelling economic growth. However, these studies have not considered Israel, which has a solid base for ICT and rich history for tourism development. Thus, by undertaking this study, we examine the magnitude and the causality effects of the two sectors on the growth of Israel.

\section{Modelling strategy}

\subsection{Modelling framework}

We use an approach used by Sturm (1998), Rao (2010) and Shahiduzzaman et al. (2015), which is related to Solow's (1956) methodology. The general equation is given as:

$$
Y_{t}=A_{t} K_{t}^{\alpha} L_{t}^{\beta}
$$

where $\mathrm{A}$ is the stock of technological knowledge, $\mathrm{K}$ and $\mathrm{L}$ are the capital and labour stock, respectively; $\alpha$ and $\beta$ are capital and labour shares respectively. Hence assuming constant returns to scale $(\beta=1-\alpha)$, we have:

$$
y_{t}=A_{t} k_{t}^{\alpha}, \alpha>0
$$

where $k=K / L$ and $y=Y / L$. The model assumes that the evolution of technology is given by: 


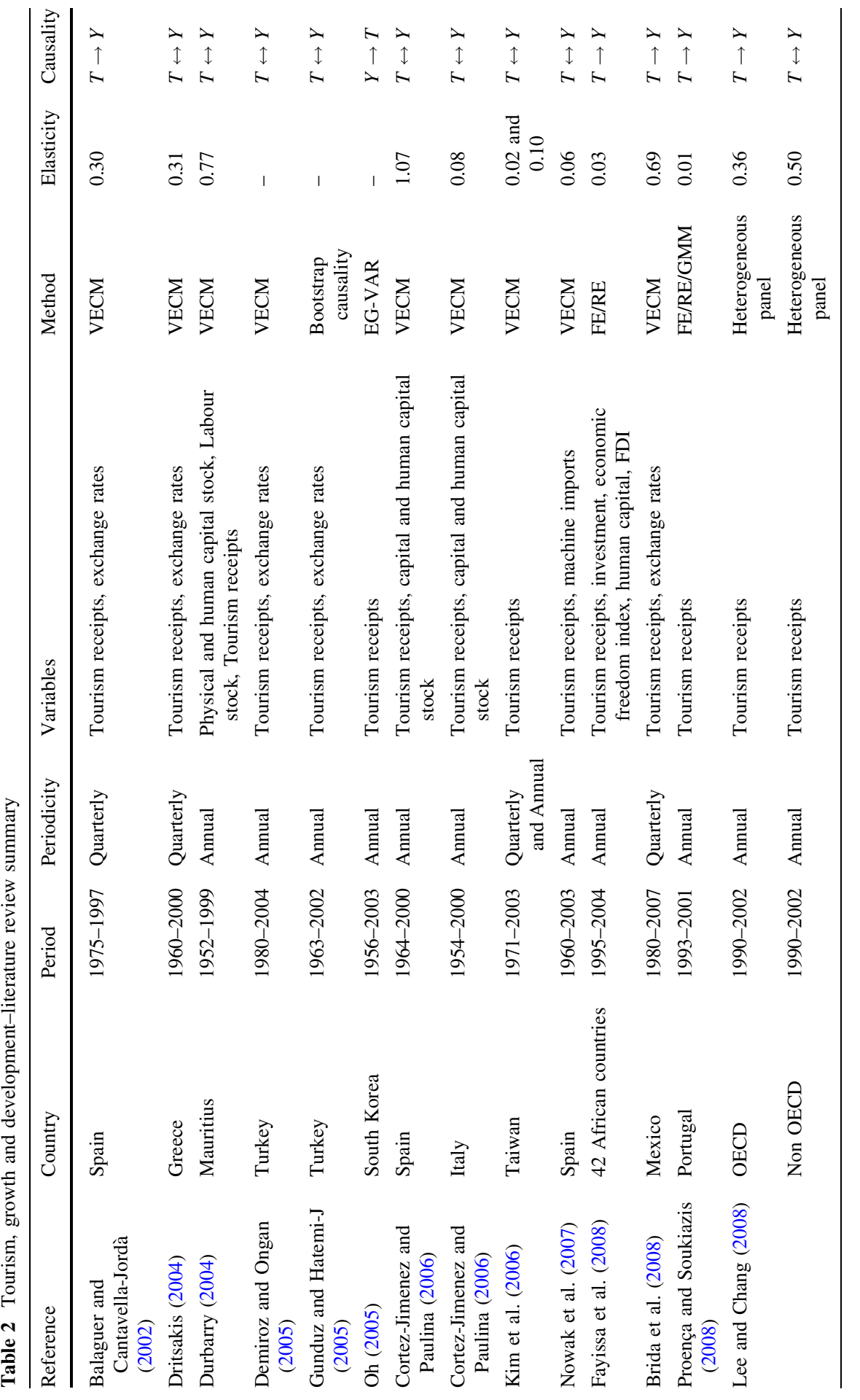




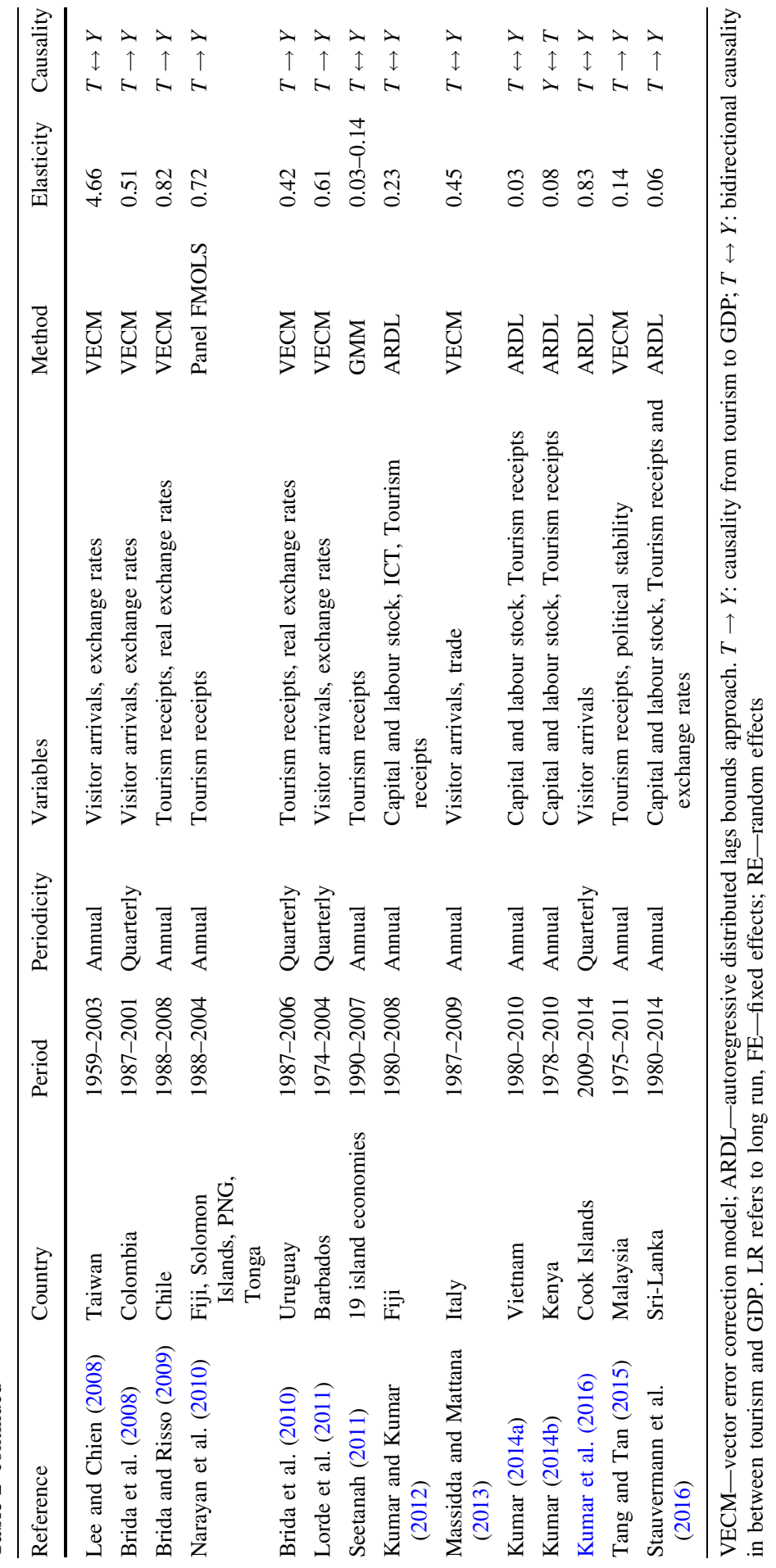




$$
\Phi_{t}=\mathrm{A}_{0} e^{g t}
$$

where $\mathrm{A}_{0}$ is the initial stock of knowledge and $t$ is time. We introduce mobile cellular technology users per worker $\left(i c t_{t}\right)$ and visitor arrivals per worker $\left(v s t_{t}\right)$ as shift variables (Rao 2010):

$$
\Psi_{t}=f\left(i c t_{t}, v s t\right)=i c t_{t}^{\theta} v s t_{t}^{\gamma}
$$

where $\theta>0$ and $\gamma>0$ represents the elasticity of mobile technology and visitor arrivals, respectively. Hence:

$$
A_{t}=\Phi_{t} \Psi_{t}=\mathrm{A}_{0} e^{g t} i c t_{t}^{\theta} v s t_{t}^{\gamma}
$$

Finally, including this information in (2), we get:

$$
y_{t}=\left(\mathrm{A}_{0} e^{g t} i c t_{t}^{\theta} v s t_{t}^{\gamma}\right) k_{t}^{\alpha}
$$

Taking the $\log$ of (6), we derive the basic model for estimation as:

$$
\ln y_{t}=\vartheta+g t+\alpha^{L R} \ln k_{t}+\theta^{L R} \ln i c t_{t}+\gamma^{L R} \ln v s t_{t}+\mu^{L R} T B+\varepsilon_{t}
$$

where $\vartheta$ is the constant, $\mathrm{g}$ is the coefficient of the time trend- $\mathrm{t}$, included if significant, $\alpha^{L R}, \theta^{L R}, \gamma^{L R}$ and $\mu^{L R}$ are the long run coefficients of $\ln k_{t}, \ln i c t_{t}, \ln v s t_{t}$ and the structural break dummy $(T B)$ respectively.

\subsection{Estimation technique}

\subsubsection{ARDL bounds procedure}

We use the autoregressive distributed lag (ARDL) procedure (Pesaran et al. 2001). The approach is preferable because unlike some other cointegration methods such as Engle and Granger (1987) and Johansen and Juselius (1990), the bound testing approach works well as long as the combination of the order of intergration does not exceed 2, which implies that at most, all the variables are stationary in the first difference (Kumar et al. 2015). Additionally, ARDL procedure is considered relatively simple and suitable for small sample size (Odhiambo 2009). Thus, we check for the unit root properties to ensure that all variables are at most stationary after first difference. Further, we identify break points in the dependent variable prior to executing the bounds procedure. The following equation is specified in the ARDL form:

$$
\begin{aligned}
\Delta \ln y_{t}= & \lambda\left[\ln y_{t-1}-\vartheta-g t-\alpha^{L R} \ln k_{t-1}-\theta^{L R} \ln i c t_{t-1}-\gamma^{L R} \ln v s t_{t-1}-\mu^{L R} T B\right] \\
& \times \sum_{i=1}^{p} \rho_{i}^{S R} \Delta \ln y_{t-i}+\sum_{i=0}^{p} \alpha_{i}^{S R} \Delta \ln k_{t-i}+\sum_{i=0}^{p} \theta_{i}^{S R} \Delta \ln i c t_{t-i} \\
& +\sum_{i=0}^{p} \gamma_{i}^{S R} \Delta \ln v s t_{t-i}+\mu^{S R} \Delta T B+u_{t}
\end{aligned}
$$

The terms in the square parenthesis [.] is the implicit one period lagged error correction term. Stability and convergence property in Eq. (8) requires the effect of 
the error correction term to be between zero and negative one. Banerjee et al. (1986) suggest that it is preferable to carry out the estimation of long run and short run parameters in a single step to avoid small sample bias inherent with the Engle and Granger (1987) two-step procedure. Accordingly, for convenience, we specify Eq. (8.1):

$$
\begin{aligned}
\Delta \ln y_{t}= & \beta_{10}+\beta_{11} \ln y_{t-1}+\beta_{12} \ln k_{t-1}+\beta_{13} \ln i c t_{t-1}+\beta_{14} \ln v s t_{t-1}+\phi_{10} T B \\
& +\varphi_{10} T+\sum_{i=1}^{p} \rho_{i}^{S R} \Delta \ln y_{t-i}+\sum_{i=0}^{p} \alpha_{i}^{S R} \Delta \ln k_{t-i}+\sum_{i=0}^{p} \theta_{i}^{S R} \Delta \ln i c t_{t-i} \\
& +\sum_{i=0}^{p} \gamma_{i}^{S R} \Delta \ln v s t_{t-i}+\mu^{S R} \Delta T B+u_{t}
\end{aligned}
$$

A dummy $(T B)$ is associated to represent the structural breaks in the dependent level series. The breaks are identified using the Bai and Perron (1998, 2003a, b) test for structural breaks.

The co-integration is identified in two steps. First, Eq. (8.1) is estimated using the ordinary least squares technique. The second step involves testing the null hypothesis of no co-integration $\left(H_{N U L L}: \beta_{11}=\beta_{12}=\beta_{13}=\beta_{14}=0\right)$ against the alternative hypothesis of the existence of a long run relationship $\left(H_{A L T}: \beta_{11} \neq 0 ; \beta_{12} \neq 0 ; \beta_{13} \neq 0 ; \beta_{14} \neq 0 ; \beta_{15} \neq 0\right)$. The existence of a long run cointegration relationship is examined by reviewing the corresponding F-statistics against its respective upper and lower bounds. Hence, we reject the null hypothesis of no cointegration when F-statistics is above the upper bound $\left\{F-\right.$ stat $\left.>I(1)_{\text {critical }}\right\}$ and do not reject the null when F-statistics is below the lower bound $\left\{F-\right.$ stat $\left.<I(0)_{\text {critical }}\right\}$. In the case when the F-statistics is within the upper and lower bounds, $\left\{I(0)_{\text {critical }}<F-\right.$ stat $\left.<I(1)_{\text {critical }}\right\}$, the outcome is inconclusive. ${ }^{5}$ We compute sample specific bounds using Eviews 9 which produces critical value bounds at the 10, 5 and $1 \%$ levels of significance. Moreover, we also use the bounds reported by Narayan (2005) for the small sample size $30 \leq n \leq 80$ to support the decision regarding cointegration. After confirming the cointegration, the next step is to estimate the long-run and short-run results, and examine the respective diagnostic tests to ensure the model is dynamically stable.

\subsubsection{VECM causality analysis}

To gain greater insights into cause and effect, causality analysis becomes useful. In addition to highlighting the different direction of influences, the causality results underscore the presence of endogeneity. It must be noted that the ARDL procedure used to estimate the long-run and short-run results minimizes endogeneity bias since the lagged variables entered into the estimation acts as instruments. However, the procedure does not directly proceed to causality. Thus, for the causality, we use the

\footnotetext{
5 However, this may be overcome by using different cointegration techniques-examining the acceptable levels of significance, and/or using theoretical justification to support the conclusion.
} 
vector error correction models (VECM) which is a suitable approach in the presence of cointegration. The following VECMs are specified below:

$$
\begin{aligned}
\Delta \ln y_{t}= & \phi_{10}+\vartheta_{10} t+\vartheta_{11} B+\sum_{i=1}^{p_{1}} \gamma_{1 i} \Delta \ln y_{t-i}+\sum_{i=0}^{p_{2}} \delta_{1 i} \Delta \ln k_{t-i}+\sum_{i=0}^{p_{3}} \theta_{1 i} \Delta \ln v s t_{t-i} \\
& +\sum_{i=0}^{p_{4}} \theta_{1 i} \Delta \ln I C T_{t-i}+\lambda_{1} E C T_{1, t-1}+\varepsilon_{1 t}
\end{aligned}
$$

$$
\begin{aligned}
\Delta \ln k_{t}= & \phi_{20}+\vartheta_{20} t+\vartheta_{21} B+\sum_{i=1}^{p_{1}} \gamma_{2 i} \Delta \ln y_{t-i}+\sum_{i=0}^{p_{2}} \delta_{2 i} \Delta \ln k_{t-i}+\sum_{i=0}^{p_{3}} \theta_{2 i} \Delta \ln v i s_{t-i} \\
& +\sum_{i=0}^{p_{4}} \theta_{2 i} \Delta \ln I C T_{t-i}+\lambda_{2} E C T_{2, t-1}+\varepsilon_{2 t}
\end{aligned}
$$

$$
\begin{aligned}
\Delta l n v i s_{t}= & \phi_{30}+\vartheta_{30} t+\vartheta_{31} B+\sum_{i=1}^{p_{1}} \gamma_{3 i} \Delta \ln y_{t-i}+\sum_{i=0}^{p_{2}} \delta_{3 i} \Delta \ln k_{t-i}+\sum_{i=0}^{p_{3}} \theta_{3 i} \Delta \ln v i s_{t-i} \\
& +\sum_{i=0}^{p_{4}} \theta_{3 i} \Delta \ln I C T_{t-i}+\lambda_{3} E C T_{3, t-1}+\varepsilon_{t}
\end{aligned}
$$

Equations (9) to (11) test causality via joint restrictions. Short-run causality from $\operatorname{lnvst}_{t}$ to $\ln _{t}, \ln _{t}$ to $\ln _{t}$ and $\ln I C T_{t}$ to $\ln y_{t}$ Eq. (9) implies that $\theta_{1 \mathrm{i}} \forall \mathrm{i} \neq 0, \delta_{1 \mathrm{i}} \forall \mathrm{i} \neq 0$ and $\theta_{1 \mathrm{i}} \forall \mathrm{i} \neq 0$; the causality from ${\ln v s t_{t}}_{\text {to }} \ln k_{t}, \ln y_{t}$ to $\ln k_{t}$ and $\operatorname{lnICT_{t}}$ to $\ln k_{t}$ Eq. (10) implies that $\theta_{2 \mathrm{i}} \forall \mathrm{i} \neq 0$ and $\delta_{2 \mathrm{i}} \forall \mathrm{i} \neq 0$; and the causality from $\ln k_{t}$ to $\ln v i s_{t}$ and $\ln _{t}$ to lnvis $_{t}$ Eq. (11) implies that $\theta_{3 \mathrm{i}} \forall \mathrm{i} \neq 0$ and $\delta_{3 \mathrm{i}} \forall \mathrm{i} \neq 0$.

It is important to examine the properties of the inverse roots of the AR (autoregressive) characteristics polynomial diagram to ensure the VECM results are dynamically stable and robust. As a criteria, the inverse roots, $I_{R}$, should lie within the positive and negative unity i.e. $-1 \leq I_{R} \leq 1$. If the roots lie outside the unit circle, then this should be corrected through appropriate re-specification of the VECM system, that is including lagged variables a instruments, break dummies and trend variable, as necessary.

\section{Data and results}

\subsection{Sample description}

We use the perpetual inventory method to build data for capital stock. We assume a depreciation rate $(\delta)$ of 0.09 and an initial capital stock $\left(K_{O}\right)$ which is 1.2 times the 
real GDP (gross domestic product) of 1960 in 2005 USD prices. ${ }^{6}$ Annual data is from 1960 to 2016, spanning over 57 years. The GDP in constant 2010 US\$, gross fixed capital formation at in constant 2010 US\$ (proxy for investment), visitor arrivals, ${ }^{7}$ and mobile subscription (\% population) ${ }^{8}$ are sourced from World Development Indicators and Global Development Finance database (World Bank 2017). The data for gross fixed capital formation $\left(I_{\text {real }}=I_{t}\right)$ is computed based on the ratio of gross fixed capital formation to GDP. The ratio $=\frac{I_{\text {current }}}{Y_{\text {current }}}=\frac{P_{t} \times I_{\text {real }}}{P_{t} \times Y_{\text {real }}}=\frac{I_{\text {real }}}{Y_{\text {real }}} \rightarrow \cong I_{\text {real }}=$ ratio $\times Y_{\text {real }}$, where $P_{t}$ is the price level at time $t$. The capital stock data is created using the perpetual inventory method: $K_{t}=(1-) K_{t-1}+I_{t}$. We note that the data for mobile cellular subscription per 100 people (mobile subscriptions as a percent of population) is only available from 1990 to 2016. To overcome the resulting problem of small data, we examined the trend and used the exponential growth-rate formula to backward approximate the data for earlier periods as: $I C T_{t-1}=\exp \left(\left(\ln I C T_{t}\right)+\bar{g}_{I C T}\right)$, where $I C T_{t-1}$ refers to the previous period data which is calculated using the current period data $\left(I C T_{t}\right)$ and the average growth rate $\bar{g}_{I C T}$, of the actual data points in the series. As expected, the data points for periods before 1990 are close to zero which is due to developments in ICT and more specifically, mobile cellular technology only gained momentum in terms of availability, accessibility and affordability by the early 1990s. ${ }^{9}$

Further, the data for visitor arrival (VST) is available only from 1995, and hence the same method is used to build the dataset from 1960 to 1994 and 2016, i.e. $V S T_{t-1}=\exp \left(\left(\ln V S T_{t}\right)+\bar{g}_{V S T}\right)$, where $\bar{g}_{V S T}$ is the average growth of visitor arrivals based on data from 1995 to 2015 . The labour stock data, which is held fixed at the average growth rate of $46.63 \%$ from 1963 to 1976, and varied for all other periods since the actual data are available from 1977 to 2016. Hence, the employment ratio is multiplied with annual population to compute the stock of labour. The descriptive statistics and correlation matrix of all variables in its original form over the sample periods 1960-2016 are represented in Table 3. The smooth trend from 1960 to 1994 for ICT (mobile cellular subscription) and visitor arrival is due to the average constant growth assumption based on post-1994 data (Fig. 3). All variables are transformed into natural logarithmic form before proceeding with the analysis.

\footnotetext{
${ }^{6}$ Elekdag et al. (2006) used $\delta=0.10$. The choice of factor used to set the initial capital stock and depreciation rate is based on two considerations: (a) capital per worker should exhibit diminishing returns to scale and (b) estimated capital share should revolve around stylised value of 0.33 (Kumar et al. 2017a, b; Bosworth and Collins 2008).

7 Note that data available on tourism earnings in WDI are from 1995 to 2011. Therefore, we impute the data from 1970 to 1994 which is approximated using the average growth rate formula. That is, $t u_{t}=\exp ^{\left(\ln \left(t u_{t-1}\right)+\hat{g}_{t u}\right)}$ where $\hat{g}_{t u}$ is the average growth rate of tourism (\% GDP) for the actual data.

${ }^{8}$ The ratio of internet users to total population (\%) is very close to zero over the period 1970-1995, given that internet and computer technology were in their infancy during this period.

9 Therefore, the numbers close to zero indicates the apparent absence of mobile technology. We assert that a number close to, but not necessarily zero, is also indicative of the fact R\&D in mobile and innovative technology was in existence in the early 1970s, at least in the form of idea and in some sense, physical presence. Also, we note that the first commercial PC 'Programma 101' from Olivetti was sold in 1965 and the first commercial cell phone Dyna TAC from Motorola was offered 1973.
} 
Table 3 Descriptive statistics and correlation matrix (1960-2016) Source: Authors' calculated using Eviews 9

\begin{tabular}{|c|c|c|c|c|c|c|}
\hline Statistics & $\begin{array}{l}\text { Output per } \\
\text { worker in } \\
\text { constant } 2010 \\
\text { US\$ (y) }\end{array}$ & $\begin{array}{l}\text { Capital per } \\
\text { worker in } \\
\text { constant } 2010 \\
\text { US\$ (k) }\end{array}$ & $\begin{array}{l}\text { Mobile } \\
\text { subscription } \\
\text { per worker } \\
(\%)(\mathrm{mob})\end{array}$ & $\begin{array}{l}\text { Visitor } \\
\text { arrivals } \\
\text { (va) }\end{array}$ & $\begin{array}{l}\text { Visitor } \\
\text { arrivals per } \\
\text { worker (\%) } \\
\text { (vst) }\end{array}$ & $\begin{array}{l}\text { Tourism } \\
\text { receipts } \\
\text { (\% GDP) } \\
\text { (tur) }\end{array}$ \\
\hline Mean & $41,074.23$ & $92,435.43$ & 37.29 & $1,957,573$ & 90.76 & 13.98 \\
\hline Median & $41,700.34$ & $99,702.96$ & 0.21 & $1,903,000$ & 96.58 & 6.63 \\
\hline Maximum & $58,390.47$ & $133,617.9$ & 133.46 & $2,962,000$ & 149.19 & 55.97 \\
\hline Minimum & $16,730.06$ & $18,403.06$ & $<0.01$ & 862,000 & 27.03 & 1.95 \\
\hline SD & $12,519.15$ & $35,651.22$ & 53.36 & 460,595 & 29.99 & 15.31 \\
\hline Skewness & -0.37 & -0.63 & 0.88 & 0.43 & -0.10 & 1.31 \\
\hline Kurtosis & 1.93 & 2.13 & 1.91 & 3.16 & 2.25 & 3.40 \\
\hline $\begin{array}{c}\text { Normality } \\
\text { (Jarque- } \\
\text { Bera) }\end{array}$ & 4.03 & 5.57 & 10.13 & 1.80 & 1.43 & 16.58 \\
\hline Probability & 0.13 & 0.06 & 0.01 & 0.41 & 0.49 & $<0.01$ \\
\hline \multicolumn{7}{|c|}{ Correlation matrix } \\
\hline$y$ & 1.00 & - & - & - & & \\
\hline$y$ & $0.99^{*}$ & 1.00 & - & - & & \\
\hline$m o b$ & $0.78^{*}$ & $0.72^{*}$ & 1.00 & - & & \\
\hline$v a$ & $0.57^{*}$ & $0.54^{*}$ & $0.46^{*}$ & 1.00 & & \\
\hline vst & $-0.94^{*}$ & $-0.94^{*}$ & $-0.81^{*}$ & $-0.35^{*}$ & 1.00 & \\
\hline tur & $-0.92^{*}$ & $-0.96^{*}$ & $-0.54^{*}$ & $-0.52^{*}$ & $0.88^{*}$ & 1.00 \\
\hline
\end{tabular}

*Indicates $p$ value $<0.01$

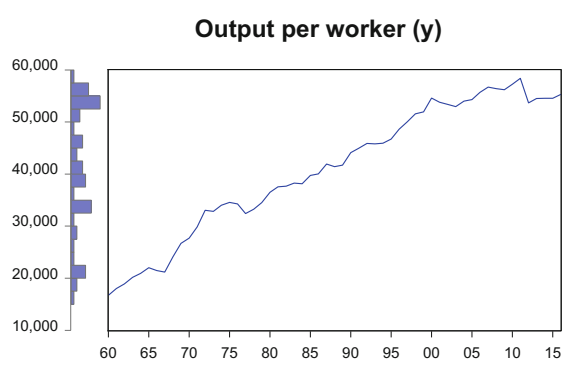

Mobile cellular subscription (\% workers)

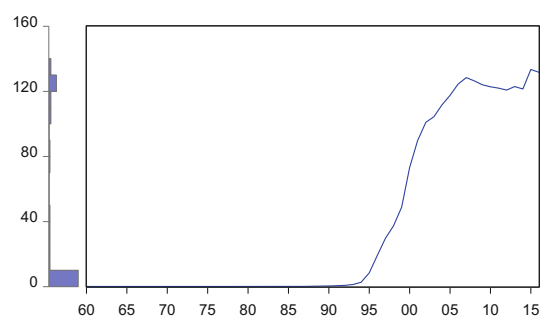

Capital per worker (k)

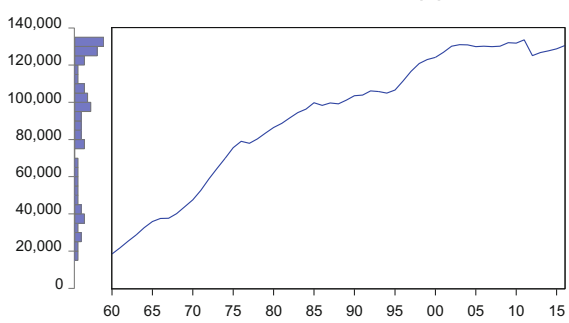

Visitor arrival (\% workers)

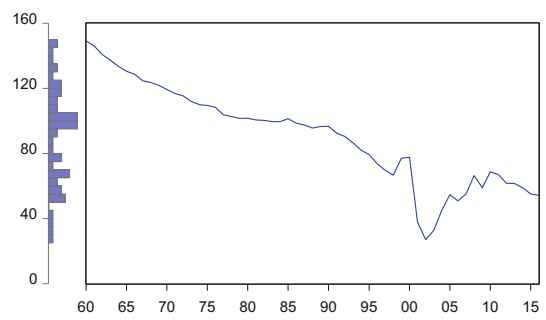

Fig. 3 Trends of key variables 
Table 4 Unit root test results

\begin{tabular}{|c|c|c|c|c|}
\hline \multirow[t]{2}{*}{ Variables in $\log$ form } & \multicolumn{2}{|l|}{ Intercept } & \multicolumn{2}{|c|}{ Intercept and trend } \\
\hline & Level & 1st diff. & Level & 1st diff. \\
\hline \multicolumn{5}{|c|}{ Augmented Dickey Fuller (ADF) } \\
\hline $\ln y$ & $-4.02[0]^{* *}$ & $-5.84[0]^{* * *}$ & $-1.82[0]$ & $-6.71[0]^{* * *}$ \\
\hline $\ln k$ & $-3.62[1]^{*}$ & $-3.39[0]^{* *}$ & $-2.66[1]$ & $-4.07[0]^{* *}$ \\
\hline $\ln m o b$ & $-1.37[1]$ & $-1.90[0]$ & $-2.04[1]$ & $-2.09[0]$ \\
\hline $\ln v s t$ & $-1.27[2]$ & $-7.04[1]^{* * * *}$ & $-2.36[2]$ & $-6.98[1]^{* * *}$ \\
\hline \multicolumn{5}{|l|}{ Phillips and Peron (PP) } \\
\hline $\ln y$ & $-4.07[3]^{* * *}$ & $-5.81[2]^{* * * *}$ & $-1.83[2]$ & $-6.68[4]^{* * *}$ \\
\hline $\ln k$ & $-8.92[2]^{* * *}$ & $-3.34[5]^{* *}$ & $-4.40[2]^{* *}$ & $-3.92[4]^{* *}$ \\
\hline $\ln m o b$ & $-1.18[5]$ & $-2.04[6]$ & $-0.84[5]$ & $-2.20[6]$ \\
\hline ln vst & $-1.27[11]$ & $-8.59[51]^{* * *}$ & $-2.65[6]$ & $-8.64[52]^{* * *}$ \\
\hline \multicolumn{5}{|c|}{ Kwiatkowski-Phillips-Schmidt-Shin (KPSS) } \\
\hline $\ln y$ & $0.86[6]$ & $0.71[3]^{*}$ & $0.23[5]$ & $0.05[3]^{* * *}$ \\
\hline $\ln k$ & $0.81[6]$ & $0.83[5]$ & $0.25[5]$ & $0.18[4]^{*}$ \\
\hline $\ln m o b$ & $0.90[6]$ & $0.22[5]^{* * *}$ & $0.11[5]^{* * * *}$ & $0.15[5]^{*}$ \\
\hline $\ln v s t$ & $0.91[5]$ & $0.14[3]^{* * * *}$ & $0.07[4]^{* * *}$ & $0.13[16]^{* * *}$ \\
\hline
\end{tabular}

The ADF and PP critical values are based on Mackinnon (1996). The KPSS is based on Kwiatkowski et al. (1992). The optimal lag is based on the Akaike Information Criterion for ADF, while the bandwidth for PP and KPSS are automatically determined by Eviews. The null hypothesis for ADF and Phillips-Perron tests is that a series has a unit root (non-stationary) and for KPSS that the series is stationary. [] indicates the automatically selected lag-length and bandwidth based on SIC and NeweyWest criteria for ADF, and PP and KPSS, respectively. ${ }^{* * *},{ }^{* *}$ and ${ }^{*}$ denotes 1, 5 and $10 \%$ level of significance at which the respective series are stationary. Source: Authors' estimation using Eviews 9

\subsection{Unit root test results}

The unit root test is conducted (a) to ensure that the series are at most a combination of $\mathrm{I}(0)$ and $\mathrm{I}(1)$ in order to use the ARDL method; (b) to confirm using a cointegration approach instead of the traditional ordinary least squares (OLS) method which is not recommended in the presence of unit root; and (c) to obtain information on the maximum lags and/or structural breaks to be used in the ARDL estimation, and partly derive information for lag-lengths to be used for causality analysis.

Table 4 presents the results for the unit root based on the augmented DickeyFuller (ADF), Phillips-Perron (PP) and Kwiatkowski, Phillips, Schmidt and Shin (KPSS) test, respectively. As noted, the maximum order of integration is one.

\subsection{Structural breaks}

Although the presence of structural breaks can influence the bounds F-statistics and hence the inference on cointegration, this is not captured by the conventional unit root tests (ADF, PP and KPSS). We use the Bai and Perron (1998, 2003a, b) multiple break test to identify the break periods. Pesaran and Timmermann (2002) 
Table 5 Bai-Perron break test on $\ln y$

\begin{tabular}{lcc}
\hline Break test & Scaled F-statistic & Critical value $^{\mathrm{a}}$ \\
\hline 0 versus $1^{*}$ & 20.56 & 11.47 \\
1 versus 2* & 33.22 & 12.95 \\
2 versus 3* & 177.09 & 14.03 \\
3 versus 4* & 69.87 & 14.85 \\
4 versus 5* & 17.72 & 15.29 \\
\hline Break dates & Sequential & Repartition \\
\hline 1 & 1972 & 1972 \\
2 & 2000 & 1980 \\
3 & 2009 & 1990 \\
4 & 1980 & 1998 \\
5 & 1990 & 2009 \\
\hline
\end{tabular}

*Indicates significance at $5 \%$

${ }^{a}$ Bai and Perron (2003b) critical values

list some of this tests advantage such as detecting multiple break points, relating these breaks with actual historical events and, by restricting the model, the procedure allows for breaks that only affect some of the regression coefficients.

Table 5 presents the breaks in the output per worker series. The breaks are noted in 1972, 1980, 1990, 1998 and 2009. These events could well represent the contemporaneous or lagged effects of the numerous economic and political events such as the 1972 Palestinian Black September hostage crisis leading to the expulsion of the PLO from Jordan to the Lebanon. In 1973, the OPEC (Organization of the Petroleum Exporting Countries) reduced dramatically its oil production with the consequence that the first world-wide oil crisis occurred; and a coalition of Arab countries led by Syria and Egypt, and supported by the Soviet Union begun the Yom Kippur war, which was won by Israel after 20 days. However, during these periods, Israel experienced substantial losses of human life, military aircraft, tanks and armoured vehicles. The immediate political consequence was the resignation of the Israel's Prime Minister Golda Meir in 1974, and the installation of the first rightwing and more market-oriented LIKUD government. This event, combined with the change of public awareness, was accompanied by a dramatic increase in military expenditures of nearly $150 \%$ measured in real terms (CBS 2014) in the period 1969-1975 peaking in 1975 at around 30\% of GDP. Defence expenditures remained relatively high until the mid-1980s, averaging around $20 \%$ of GDP. Not surprisingly, these events resulted in negative income and growth rates with the periods 1973-1985 becoming known as the 'Lost Decade' in Israel. Moreover, during the period 1987-1991, the Hamas movement quickly escalated violence against Israel and in 1991; Israel was on the receiving end of 39 scud missiles launched by Iraq in an attempt to regionalize the on-going gulf war. The period 1998 may represent the effect of the Kfar Darom and the Jerusalem bombing while 2009 could represent the combined lagged effect of the global financial crisis and 
the ongoing Isreal-Gaza conflict. Nonetheless, the periods are also marked with positive events such as the Camp David Accords and the Oslo Accord in an attempt to resolve the Israeli-Egyptian and Israeli-Palestinian conflicts, respectively. These opposing events are likely to create indeterminate effects on economic activity and we hence make no prediction for their subsequent effects on economic activity.

\subsection{Lag-length test}

Table 6 presents the results of the lag selection. As noted, a maximum lag-length of two is desirable based on the given criteria. Thus, a lag-length of two is used for ARDL estimation, which produces the cointegration F-statistics, long-run and shortrun results by identifying the optimum lags from 9 but not exceeding 2 .

Additionally, we factor the information on structural breaks (Table 5) with a dummy variable when carrying out the bounds procedure for cointegration. Table 7 presents the bounds test results with evidence of long-run cointegration with structural break (F-statistics $=3.41)$ and without breaks $($ F-statistics $=3.71)$, since in both instances, the respective F-statistics exceed the upper I(1) bounds of 3.20 (Pesaran et al. 2001) and 3.36 (Narayan 2005).

The next step is to examine the diagnostic test statistics from the lag-estimates before estimating the long-run and the short-run coefficients. For the diagnostic test

Table 6 Results of lag order selection criteria

\begin{tabular}{lllllll}
\hline Lag & LL & LR & FPE & AIC & SC & HQ \\
\hline 1 & 297.46 & - & $2.87 \times 10^{-10}$ & -10.62 & -10.03 & -10.39 \\
2 & $\mathbf{3 5 4 . 0 7}$ & $\mathbf{9 6 . 1 3}^{\mathrm{A}}$ & $\mathbf{6 . 2 5} \times \mathbf{1 0}^{\mathbf{- 1 1 A}}$ & $\mathbf{- 1 2 . 1 5 ^ { \mathrm { A } }}$ & $-\mathbf{1 0 . 9 6}^{\mathrm{A}}$ & $\mathbf{- 1 1 . 7 0 ^ { \mathrm { A } }}$ \\
3 & 361.00 & 10.73 & $9.00 \times 10^{-11}$ & -11.81 & -10.03 & -11.13 \\
4 & 371.24 & 14.29 & $1.70 \times 10^{-10}$ & -11.59 & -9.21 & -10.68 \\
\hline
\end{tabular}

A indicates lag order selected by the criterion

$L R$ sequential modified LR test statistic (each test at 5\% level); FPE final prediction error; AIC Akaike information criterion; SC Schwarz information criterion; $H Q$ Hannan-Quinn information criterion

The highlighted row indicates the lag-selected based on the significance of the majority of the criteria

Table 7 Bounds test results-ARDL $(2,2,0,1)$

\begin{tabular}{|c|c|c|c|c|}
\hline \multicolumn{4}{|l|}{ Equation } & \multirow{2}{*}{$\frac{\text { F-statistics }}{3.41^{*}}$} \\
\hline \multicolumn{4}{|c|}{ Break included: $\ln y_{t} \mid \ln k_{t}, \ln$ moblnvst $_{t} ; T B$} & \\
\hline \multicolumn{4}{|c|}{ Break excluded: $\ln y_{t} \mid \ln k_{t}, \ln m o b, \ln v i s_{t}$} & $3.71^{* *}$ \\
\hline \multirow[t]{2}{*}{ Critical value bounds $(\%)$} & \multicolumn{2}{|c|}{ Pesaran et al. (2001) } & \multicolumn{2}{|c|}{ Narayan (2005) } \\
\hline & $\mathrm{I}(0)$ Bound & I(1) Bound & $\mathrm{I}(0)$ Bound & I(1) Bound \\
\hline 10 & 2.37 & $3.20 *$ & 2.51 & $3.36^{*}$ \\
\hline 5 & 2.79 & $3.67 * *$ & 2.98 & 3.94 \\
\hline 1 & 3.65 & 4.66 & 4.12 & 5.20 \\
\hline
\end{tabular}

$*$ and $* *$ indicates support for cointegration at $5 \%$ and $10 \%$ level, respectively 
Table 8 Short-run: dependent variable $(\Delta \boldsymbol{l n y})$

\begin{tabular}{lllll}
\hline Regressor & Coefficient & SE & T-ratio & $p$ value \\
\hline$\Delta \ln y_{t-1}\left(\rho_{1}^{S R}\right)$ & $0.29^{* * *}$ & 0.088 & 3.34 & $<0.01$ \\
$\Delta \ln k_{t}\left(\alpha_{1}^{S R}\right)$ & $1.03^{* * *}$ & 0.099 & 10.34 & $<0.01$ \\
$\Delta \ln k_{t-1}\left(\alpha_{2}^{S R}\right)$ & $-0.72^{* * *}$ & 0.100 & -7.14 & $<0.01$ \\
$\Delta \operatorname{lnict}\left(\theta_{1}^{S R}\right)$ & 0.01 & 0.009 & 0.91 & 0.37 \\
$\Delta \ln v s t\left(\gamma_{1}^{S R}\right)$ & $0.06^{* * *}$ & 0.018 & 3.21 & $<0.01$ \\
$\Delta T B\left(\mu^{S R}\right)$ & $0.02^{* * *}$ & 0.006 & 4.35 & $<0.01$ \\
$E C M_{t-1} .(\lambda)$ & $-0.28^{* * *}$ & 0.060 & -4.70 & $<0.01$ \\
$E C M=\ln _{y}-\left(0.43 * \ln _{k}+0.03 * \ln _{i c t}+0.04 * \ln _{v s t}+0.10 * B R E A K+5.50.\right)$ & \\
$R^{2}=0.79 . ; \bar{R}^{2}=0.74 ;$ & ARDL $(2,2,0,1) ; F-S t a t .(7,47)=23.99 ; D W-$ stat. $=2.24$ & \\
\hline
\end{tabular}
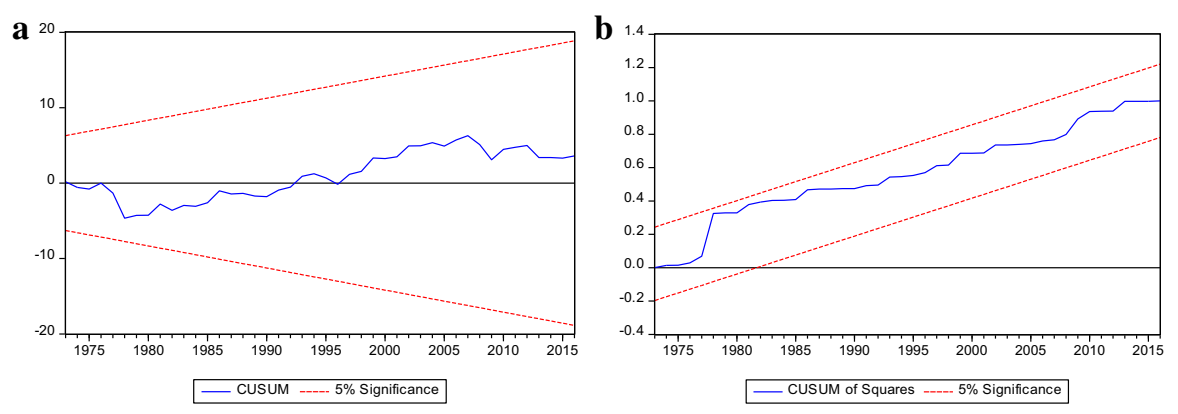

Fig. 4 CUSUM (a) and CUSUMQ (b) Plots

statistics, we examine the following: the Lagrange multiplier test of residual serial correlation $\left(\chi_{\mathrm{sc}}^{2}\right)$; Ramsey's RESET test using the square of the fitted values for correct functional form $\left(\chi_{\mathrm{ff}}^{2}\right)$; a normality test based on a test of skewness and kurtosis of residuals $\left(\chi_{\mathrm{n}}^{2}\right)$; and a heteroscedasticity test based on the regression of squared residuals on squared fitted values $\left(\chi_{\mathrm{hc}}^{2}\right)$. In cases where the respective diagnostic tests are statistically significant, then the presence of the respective biases is implied in the model. Overall, from Table 8 (lower panel) we reject the presence of biases in the model where the level of significance is at least $10 \%$ for all the diagnostic tests. Further, the cumulative sum of recursive squares (CUMUM) and cumulative sum of squares of recursive residuals (CUSUMQ) in Fig. $4 \mathrm{a}$ and $\mathrm{b}$ confirm the stability of estimated parameters of the model.

\subsection{Short-run and long-run result from ARDL approach}

Following the confirmation of cointegration (long-run association) between output per worker, capital per worker, ICT and visitor arrival, we estimate short-run (Table 9) and long-run (Table 10) results. 
Table 9 Long-run: dependent variable $(\ln y)$

\begin{tabular}{|c|c|c|c|c|}
\hline Sor & Coefficient & SE & T-ratio & $p$ value \\
\hline $\ln k\left(\alpha^{L R}\right)$ & $0.43^{* * *}$ & 0.06 & 6.93 & $<0.01$ \\
\hline $\ln _{i c t}\left(\theta^{L R}\right)$ & $0.03^{* * *}$ & 0.01 & 4.38 & $<0.01$ \\
\hline $\ln _{v s t}\left(\gamma^{L R}\right)$ & 0.04 & 0.06 & 0.67 & 51 \\
\hline Break $\left(\mu^{L R}\right)$ & $0.10^{*}$ & 0.05 & 1.97 & 0.06 \\
\hline Constant $(\vartheta)$ & $5.50^{* * *}$ & 0.79 & 6.92 & $<0.01$ \\
\hline \multicolumn{5}{|c|}{$\begin{array}{l}R^{2}=0.99 ; \bar{R}^{2}=0.99 \operatorname{ARDL}(2,2,0,1) ; \chi_{s c}^{2}: \chi^{2}(1)=1.96[0.16], \mathrm{F}(1,44)=1.625[0.21] \\
\chi_{f f}^{2}: \chi^{2}(1)=1.50[0.22], \mathrm{F}(1,44)=1.23[0.27] ; \chi_{n}^{2}: \chi^{2}(2)=0.78[0.68] ; \chi_{h c}^{2}: \chi^{2}(1)=7.09[0.01], \\
\mathrm{F}(1,53)=7.84[0.01] ; \mathrm{SER}=0.02 ; \mathrm{SSR}=0.01 ; \bar{x}_{\ln y}=10.60 ; \hat{\sigma}_{\ln y}=0.32 ; A I C=138.67 ; \\
S B C=128.63 ; L L=148.67 ; F-\text { Stat. }(9,45)=1926.8 ; D W-\text { stat. }=2.24\end{array}$} \\
\hline
\end{tabular}

***, *Indicate statistical significance at 1 and $10 \%$ level, respectively

Table 10 VECM Granger non-causality test based on $\chi^{2}$. Source Authors' calculation using Eviews 9

\begin{tabular}{|c|c|c|c|c|c|}
\hline & \multicolumn{5}{|c|}{ Dependent variable $(\boldsymbol{Y})$} \\
\hline & $X$ & $\Delta \ln y$ & $\Delta \ln k$ & $\Delta \ln m o b$ & $\Delta \ln V S T$ \\
\hline \multirow{5}{*}{$\boldsymbol{X} \underbrace{\longrightarrow}_{\text {causes }} \boldsymbol{Y}$} & $\Delta \ln y$ & - & $1.15(0.77)$ & $0.17(0.98)$ & $6.14(0.11)$ \\
\hline & $\Delta \ln k$ & $8.16^{\mathrm{C}}(0.04)$ & - & $1.53(0.68)$ & $6.84^{\mathrm{B}}(0.08)$ \\
\hline & $\Delta \ln m o b$ & $8.66^{\mathrm{C}}(0.03)$ & $4.95(0.18)$ & - & $6.985^{\mathrm{B}}(0.07)$ \\
\hline & $\Delta l n v s t$ & $7.30^{\mathrm{B}}(0.06)$ & $3.30(0.35)$ & $0.20(0.98)$ & - \\
\hline & Combined & $14.50(0.11)$ & $8.18(0.52)$ & $2.17(0.99)$ & $15.64(0.08)$ \\
\hline
\end{tabular}

$\mathrm{B}$ and $\mathrm{C}$ indicates the presence of causality at 5 and $10 \%$ level of statistical significance, respectively; degrees of freedom $=3 ; p$ values are given in brackets ()

From the short-run results (Table 8), the capital per worker effects is noted at 0.32 and significant $\left(\alpha_{1}^{S R}+\alpha_{2}^{S R}=0.32\right)$, mobile cellular (ICT) technology effects is noted at $0.008\left(\theta_{1}^{S R}=0.01\right)$ but insignificant at the $10 \%$ level. The coefficient of visitor arrivals (tourism) is positive noted at $0.059\left(\gamma_{1}^{S R}=0.06\right)$ and is statistically significant within the conventional levels significance. On the other hand, we note that the structural break period $\left\{\mu^{S R}=0.02\right\}$ is statistically significant at the $1 \%$ level and has a marginal positive impact on output per worker. This implies that the shocks captured have marginal 'growth enhancing' effects. The error correction term's effect is noted at $-0.28(\lambda=-0.28)$, which measures the speed at which prior deviations (errors) from equilibrium are corrected (in this case, it is about $28 \%$ ), has a correct (negative) sign and is significant at the $1 \%$ level, indicating a relatively slow convergence to long-run equilibrium taking approximately 3.6 years during normal times.

Next, from the long-run results (Table 8), we note the capital share effect is equal to $0.43\left(\alpha^{L R}=0.43\right)$ and statistically significant at the $1 \%$ level. We note the share of capital is relatively higher than the stylized value of one-third (Rao 2010), 
although fairly close to the estimates of Elekdag et al. (2006). A relatively high capital share can be plausible for number of reasons: (a) when capital and labour inputs tend to grow at relatively similar rates; (b) when a country has large numbers of self-employed persons who derive income from both capital and their own labour (Gollin 2002) thus making it difficult to obtain meaningful measures of income shares; (c) poor quality data and small sample size making it difficult to compute capital per worker that should exhibit a smooth decreasing returns to scale and hence the steady-state convergence (Bosworth and Collins 2008). We concur to all the aforementioned reasons in the case of our own study.

Moreover, we note that the elasticity coefficient of ICT is $0.03\left(\theta^{L R}=0.03\right)$ and is highly significant at the $1 \%$ level. The elasticity coefficient of tourism is 0.04 $\left(\gamma^{L R}=0.04\right)$ although is not significant within conventional levels. This implies that, ceteris paribus, a $1 \%$ increase in mobile cellular technology subscriptions will increase the output per worker by about $0.03 \%$. We note that the effects of the structural break have similar signs as those for the short-run, indicating a clear transition of short-run effects to the long-run. ${ }^{10}$ Interestingly, only mobile cellular technology (proxy for ICT) is significant and tourism is only noted to have short run effects. Two possible reasons could be that ICT contributes to tourism (evident from the causality results in Sect. 4.6) and is the actual driver of growth in Israel, or it could just be a sample size or methodology short coming. In this regard, policies directed to improve technology use and tourism infrastructure are likely to benefit long-run growth.

\subsection{VECM Granger causality}

From the unit root results (Table 4), we note that the maximum order of integration is 1 i.e. $d_{\max }=1$, and the lag used for the ARDL estimation is $1(l=1)$. Hence, the maximum lag that can be used to carry out the non-causality test is $d_{\max }+l=2$. Further, we ensured that the causality model is dynamically stable by adhering to the condition that the inverse root of the polynomials are within the unit circle, $\left|I_{R}\right| \leq 1$ (Fig. 5). The results of the causality tests are presented in Table 10. They show a unidirectional causality from ICT to output per worker $\left(\ln i c t \rightarrow \ln y: \chi^{2}=8.66\right)$ at the $5 \%$ level of statistical significance-thus supporting the Tech-LG hypothesis. Moreover, a unidirectional causality is noted from tourism to output per worker at the $10 \%$ significance level $\left(\ln v s t \rightarrow \ln y: \chi^{2}=7.30\right)$ thus confirming the tourism led growth proposition in Israel. Lastly, unidirectional causality is also noted from capital to output per worker at the $5 \%$ level $\left(\ln k \rightarrow \ln y: \chi^{2}=8.16\right)$, from capital per worker to tourism $\left(\ln k \rightarrow \ln v s t: \chi^{2}=6.84\right) \quad$ at the $10 \%$ and from ICT to tourism $\left(\ln i c t \rightarrow \ln v s t: \chi^{2}=6.99\right)$ at the $10 \%$ which indicates that technology causes visitor arrivals.

\footnotetext{
$\overline{10}$ Note that the constant term is not in the short-run estimation because, mathematically, the constant cancels out when the level variables are differenced including the constant term. This is nicely treated in Mfit 5.01.
} 
Fig. 5 Inverse roots of AR characteristic polynomial

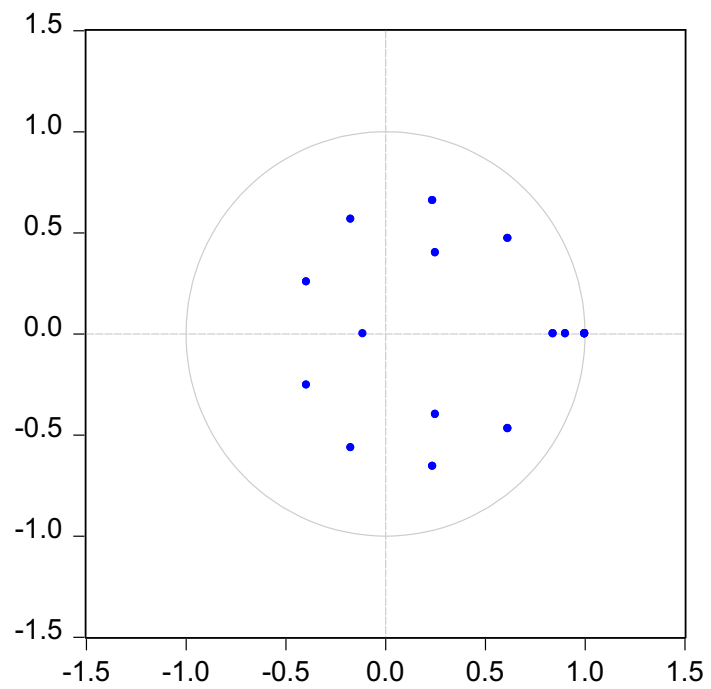

\section{Conclusions}

In this paper, we examine the role of ICT and tourism in explaining the output per worker in Israel, a country which is compelled to spend a remarkably high share of its GDP on security. Using the augmented Solow (1956) framework, the ARDL bounds procedure (Pesaran et al. 2001) and accounting for structural breaks in the series (Bai and Perron 1998, 2003a, b), we examine the long-run association. We note that capital per worker, ICT, and tourism are cointegrated with output per worker. The results show that ICT has a positive short-run and long-run impact, and that visitor arrival has a positive effect in the long-run only. The Granger causality results reveal a unidirectional causality from ICT to output per worker, and a unidirectional causality from tourism to output per worker and mobile cellular technology to visitor arrivals. However, some limitations of the study remains. First, we estimate a reduced-form model and therefore can be extended to incorporate human capital ${ }^{11}$ and exchange rate (Stauvermann et al. 2016). Second, tourism demand model for Israel can be developed to examine the tourism elasticity with respect to source country tourism. Additionally, tourism demand analysis can focus on preference model to determine the willingness to pay of tourists visiting Israel. Such studies will invoke demand side and microeconomic theories. Third, there are many indicators of ICT (Kumar et al. 2016a, b), and this can be explored in the growth model. Finally, our model can be easily revised to examine the impacts of ICT and tourism on the total factor productivity, and/or estimate the threshold effects (Kumar et al. 2017a, b; Kumar and Stauvermann 2016).

\footnotetext{
11 The authors thank an anonymous reviewer for highlighting this point. However, due to inconsistent data and small sample on human capital, it was not included.
} 
In any case, it is clear from this study that ICT is a crucial driver of economic growth in Israel and is a prime mover of critical economic activities including tourism. Specifically, this study shows that technology can be used as a means to expand tourism markets and visitor arrivals, particularly by keeping prospective tourism source markets informed and showcasing Israel as an exotic tourism destination. In particular the use of ICT to better coordinate travel and keeping (potential) visitors well informed on issues of safety and security are vital to sustain the growing visitor numbers.

With the growth in the use of mobile technology and other linked services, we assert that the gains from meshing ICT with the facilitation and development of tourism in Israel are likely to benefit the economy in the long-run. This study suggests that through this linkage there is a clear opportunity to, improve the overall tourism infrastructure, increase security and assist in the development of emerging various tourism products such those based on nature, medicine, education, religion, archaeology, and agriculture. Specifically the results of this study underscore the benefits of the effective use of technology in information sharing and creating a virtual link for international tourism. Also, devoting more resources into research in the areas of information science and technology, and the development of cuttingedge products tailored to the tourism industry can create a self-sustaining growth loop between the two sectors and for the economy as a whole.

Acknowledgements Peter J. Stauvermann acknowledges the financial support of the Changwon National University in 2017-2018 for his active research contributions. All the authors are thankful to the Editorin-Chief, Professor George Hondroyiannis, and the two anonymous reviewers for their comments and advice. The usual disclaimer applies.

\section{Compliance with ethical standards}

Conflict of interest There is no potential conflict of interest.

\section{References}

Aghion P, Howitt P (1998) On the macroeconomic effects of major technological change. In: Helpman E (ed) General purpose technologies and economic growth, 5. MIT Press, Cambridge, pp 121-144

Arora A, Athreye S (2002) The software industry and India's economic development. Inf Econ Policy 14(2):253-273

Arvanitis S, Loukis EN (2009) Information and communication technologies, human capital, workplace organization and labour productivity: a comparative study based on firm-level data for Greece and Switzerland. Inf Econ Policy 21(1):43-61

Badescu M, Garcés-Ayerbe C (2009) The impact of information technologies on firm productivity: empirical evidence from Spain. Technovation 29(2):122-129

Bai J, Perron P (1998) Estimating and testing linear models with multiple structural changes. Econometrica 66(1):47-78

Bai J, Perron P (2003a) Computation and analysis of multiple structural change models. J Appl Econ 18(1):1-22

Bai J, Perron P (2003b) Critical values for multiple structural change tests. Econ J 6(1):72-78

Balaguer J, Cantavella- Jordà M (2002) Tourism as a long-run economic growth factor: the Spanish case. Appl Econ 34(7):877-884 
Banerjee A, Dolado JJ, Hendry DF, Smith GW (1986) Exploring equilibrium relationships in econometrics through static models: some Monte Carlo evidence. Oxford Bull Econ Stat 48(3):253-277

Becchetti L, Adriani F (2005) Does the digital divide matter? The role of information and communication technology in cross-country level and growth estimates. Econ Innov New Technol 14(6):435-453

Bertschek I, Niebel T (2016) Mobile and more productive? Firm-level evidence on the productivity effects of mobile internet use. Telecommun Policy 40(9):888-898

Bertschek I, Cerquera D, Klein GJ (2013) More bits-more bucks? Measuring the impact of broadband internet on firm performance. Inf Econ Policy 25(3):190-203

Bosworth B, Collins SM (2008) Accounting for growth: comparing China and India. J Econ Perspect 22(1):45-66

Bresnahan TF, Trajtenberg M (1995) General purpose technologies 'engines of growth'? J Econ 65(1):83-108

Brida JG, Risso WA (2009) Tourism as a factor of long-run economic growth: an empirical analysis for Chile. Eur J Tour Res 2(2):178

Brida JG, Carrera EJS, Risso WA (2008) Tourism's impact on long-run Mexican economic growth. Econ Bull 3(21):1-8

Brida JG, Lanzilotta B, Lionetti S, Risso WA (2010) Research note: the tourism-led growth hypothesis for Uruguay. Tour Econ 16(3):765-771

Brynjolfsson E, Hitt LM (2003) Computing productivity: firm-level evidence. Rev Econ Stat 85(4):793-808

Buhalis D, Law R (2008) Progress in information technology and tourism management: 20 years on and 10 years after the internet-the state of eTourism research. Tour Manag 29(4):609-623

Central Bureau of Statistics (CBS) (2014) Defence Expenditure in Israel 1950-2012. CBS Publication No. 1579, Jerusalem, October 2014. http://www.cbs.gov.il/publications14/1579_defence_2012/pdf/ e_print.pdf

Chakraborty C, Nandi B (2011) 'Mainline' telecommunications infrastructure, levels of development and economic growth: evidence from a panel of developing countries. Telecommun Policy 35(5):441-449

Chang CL, Khamkaew T, McAleer M (2012) IV estimation of a panel threshold model of tourism specialization and economic development. Tour Econ 18(1):5-41

Chou YC, Chuang HHC, Shao BB (2014) The impacts of information technology on total factor productivity: a look at externalities and innovations. Int J Prod Econ 158:290-299

Colecchia A, Schreyer P (2002) ICT investment and economic growth in the 1990s: is the United States a unique case? A comparative study of nine OECD countries. Rev Econ Dyn 5(2):408-442

Comin D, Hobijn B, Rovito E (2008) Technology usage lags. J Econ Growth 13(4):237-256

Cortez-Jimenez I, Paulina M (2006) A further step into the ELGH and TOURISM-LG for Spain and Italy. Fondazione Eni Enrico Mattei Working Paper Series, Nota di Lavoro 118-2006

Cronin FJ, Parker EB, Colleran EK, Gold MA (1991) Telecommunications infrastructure and economic growth: an analysis of causality. Telecommun Policy 15(6):529-535

Datta A, Agarwal S (2004) Telecommunications and economic growth: a panel data approach. Appl Econ 36(15):1649-1654

Daveri F (2002) The new economy in Europe, 1992-2001. Oxford Rev Econ Policy 18(3):345-362

David PA (1990) The dynamo and the computer: an historical perspective on the modern productivity paradox. Am Econ Rev 80(2):355-361

Demeter K, Chikán A, Matyusz Z (2011) Labour productivity change: drivers, business impact and macroeconomic moderators. Int J Prod Econ 131(1):215-223

Demiroz DM, Ongan S (2005) The contribution of tourism to the long-run Turkish economic growth. Ekonomický časopis 9:880-894

Dewan S, Kraemer KL (2000) Information technology and productivity: evidence from country-level data. Manage Sci 46(4):548-562

Dimelis SP, Papaioannou SK (2010) FDI and ICT effects on productivity growth: a comparative analysis of developing and developed countries. Eur J Dev Res 22(1):79-96

Dritsakis N (2004) Tourism as a long-run economic growth factor: an empirical investigation for Greece using causality analysis. Tour Econ 10(3):305-316

Durbarry R (2004) Tourism and economic growth: the case of Mauritius. Tour Econ 10(4):389-401 
Elekdag S, Epstein N, Moreno-Badía M (2006) Fiscal consolidation in Israel: a global fiscal model perspective. IMF Working Paper WP/06/253, IMF. https://www.imf.org/external/pubs/ft/wp/2006/ wp06253.pdf

Engle RF, Granger CWJ (1987) Co-integration and error correction: representation, estimation, and testing. Econometrica 55(2):251-276

Erumban AA, Das DK (2016) Information and communication technology and economic growth in India. Telecommun Policy 40(5):412-431

Fayissa B, Nsiah C, Tadasse B (2008) Impact of tourism on economic growth and development in Africa. Tour Econ 14(4):807-818

Galperin H (2005) Wireless networks and rural development: opportunities for Latin America. Inf Technol Int Dev 2(3):47-56

Ghosh S (2016) Does mobile telephony spur growth? Evidence from Indian states. Telecommun Policy 40(10):1020-1031

Gollin D (2002) Getting income shares right. J Polit Econ 110(2):458-474

Gruber H, Koutroumpis P (2010) Mobile communications: diffusion facts and prospects. Commun Strateg 77(1): 133-145. https://papers.ssrn.com/sol3/papers.cfm?abstract_id=1809749

Gruber H, Hätönen J, Koutroumpis P (2014) Broadband access in the EU: an assessment of future economic benefits. Telecommun Policy 38(11):1046-1058

Gunduz L, Hatemi-J A (2005) Is the tourism-led growth hypothesis valid for Turkey? Appl Econ Lett 12(8):499-504

Hardy AP (1980) The role of the telephone in economic development. Telecommun Policy 4(4):278-286

Helpman E, Trajtenberg M (1998a) Diffusion of general purpose technologies. In: Helpman E (ed) General purpose technologies and economic growth, 3rd edn. MIT Press, Cambridge, pp 85-119

Helpman E, Trajtenberg M (1998b) A time to sow and a time to reap: growth based on general purpose technologies. In: Helpman E (ed) General purpose technologies and economic growth, 3rd edn. MIT Press, Cambridge, pp 55-83

Hofman A, Aravena C, Aliaga V (2016) Information and communication technologies and their impact in the economic growth of Latin America, 1990-2013. Telecommun Policy 40(5):485-501

Holzner M (2010) Tourism and economic development: the beach disease? Tour Manag 32(4):922-933

Hong JP (2017) Causal relationship between ICT R\&D investment and economic growth in Korea. Technol Forecast Soc Chang 116:70-75

Hulten CR (2001) Total factor productivity: a short biography. In: Hulten CR, Dean ER, Harper MJ (eds) New developments in productivity analysis, pp 1-54. University of Chicago Press. http://www.nber. org/chapters/c10122.pdf

Inklaar R, Timmer MP, Van Ark B (2008) Market services productivity across Europe and the US. Econ Policy 23(53):140-194

Ishida H (2015) The effect of ICT development on economic growth and energy consumption in Japan. Telemat Inform 32(1):79-88

Jalava J, Pohjola M (2002) Economic growth in the new economy: evidence from advanced economies. Inf Econ Policy 14(2):189-210

Jalava J, Pohjola M (2008) The roles of electricity and ICT in economic growth: case Finland. Explor Econ Hist 45(3):270-287

Jin S, Cho CM (2015) Is ICT a new essential for national economic growth in an information society? Gov Inf Q 32(3):253-260

Johansen S, Juselius K (1990) Maximum likelihood estimation and inference on cointegration-with applications to the demand for money. Oxford Bull Econ Stat 52(2):169-210

Jorgenson DW (2001) Information technology and the US economy. Am Econ Rev 91(1):1-32

Jorgenson DW (2003) Information technology and the G7 economies. World Econ 4(4):139-169

Jorgenson DW, Motohashi K (2005) Information technology and the Japanese economy. J Jpn Int Econ 19(4):460-481

Jorgenson DW, Stiroh KJ (2000) Raising the speed limit: US economic growth in the information age. Brook Papers Econ Activity 1:125-210

Jorgenson DW, Vu K (2007) Information technology and the world growth resurgence. German Econ Rev $8(2): 125-145$

Jorgenson DW, Vu KM (2011) The rise of developing Asia and the new economic order. J Policy Model 33(5):698-716

Jorgenson DW, Ho MS, Samuels JD (2016) The impact of information technology on postwar US economic growth. Telecommun Policy 40(5):398-411 
Jovanovic B, Rousseau PL (2005) General purpose technologies. In: Aghion P, Durlauf S (eds) Handbook of economic growth, vol 1. chap 18, 1 edn. Elsevier, pp 1181-1224

Jung HJ, Na KY, Yoon CH (2013) The role of ICT in Korea's economic growth: productivity changes across industries since the 1990s. Telecommun Policy 37(4):292-310

Kasahara H, Rodrigue J (2008) Does the use of imported intermediates increase productivity? Plant-level evidence. J Dev Econ 87(1):106-118

Katircioglu ST (2009) Revisiting the tourism-led-growth hypothesis for Turkey using the bounds test and Johansen approach for cointegration. Tour Manag 30(1):17-20

Kim HJ, Chen M-H, Jang SS (2006) Tourism expansion and economic development: the case of Taiwan. Tour Manag 27(5):925-933

Koutroumpis P (2009) The economic impact of broadband on growth: a simultaneous approach. Telecommun Policy 33(9):471-485

Kumar RR (2011) Nexus between financial and technology inclusion, remittances and trade openness visà-vis growth: a study of Nepal. Econ J Nepal 34(1):13-33

Kumar RR (2012) Exploring the interactive effects of remittances, financial development and ICT in SubSaharan Africa: an ARDL bounds approach. Afr J Econ Sustain Dev 1(3):214-242

Kumar RR (2013) Linking remittances with financial development and ICT: a study of the Philippines. Int J Econ Bus Res 5(4):379-399

Kumar RR (2014a) Exploring the role of technology, tourism and financial development: an empirical study of Vietnam. Qual Quant 48(5):2881-2898

Kumar RR (2014b) Exploring the nexus between tourism, remittances and growth in Kenya. Qual Quant 48(3): 1573-1588

Kumar RR, Kumar R (2012) Exploring the nexus between information and communications technology, tourism and growth in Fiji. Tour Econ 18(2):359-371

Kumar RR, Kumar R (2013) Exploring the developments in urbanisation, aid dependency, sectoral shifts and services sector expansion in Fiji: a modern growth perspective. Glob Bus Econ Rev 15(4):371-395

Kumar RR, Stauvermann PJ (2016) The linear and non-linear relationship between of tourism demand and output per worker: a study of Sri Lanka. Tour Manag Perspect 19:109-120

Kumar RR, Vu HTT (2014) Exploring the nexus between ICT, remittances and economic growth: a study of Vietnam. J Southeast Asian Econ 31(1):104-120

Kumar RR, Kumar RD, Patel A (2015a) Accounting for telecommunications contribution to economic growth: a study of Small Pacific Island States. Telecommun Policy 39(3-4):284-295

Kumar RR, Stauvermann PJ, Patel A (2015b) Nexus between electricity consumption and economic growth: a study of Gibraltar. Econ Change Restruct 48(2):119-135

Kumar RR, Loganathan N, Patel A, Kumar RD (2015c) Nexus between tourism earnings and economic growth: a study of Malaysia. Qual Quant 49(3):1101-1120

Kumar RR, Stauvermann PJ, Samitas A (2016a) The effects of ICT* on output per worker: a study of the Chinese economy. Telecommun Policy 40(2):102-115

Kumar RR, Stauvermann PJ, Patel A, Kumar N, Prasad S (2016b) Exploring the nexus between tourism and output in Cook Islands: an ARDL bounds approach. Soc Indic Res 128(3):1085-1101

Kumar RR, Stauvermann PJ, Kumar NN, Shahzad SJH (2017a) Revisiting the threshold effect of remittances on total factor productivity growth in South Asia: a study of Bangladesh and India. Appl Econ. https://doi.org/10.1080/00036846.2017.1412074

Kumar RR, Stauvermann PJ, Patel A, Kumar N (2017b) The effect of energy on output per worker in the Balkan Peninsula: a country-specific study of 12 nations in the energy community. Renew Sustain Energy Rev 70(C):1223-1239

Kuppusamy M, Raman M, Lee G (2009) Whose ICT investment matters to economic growth: private or public? The Malaysian perspective. Electr J Inf Syst Dev Ctries 37(7):1-19

Kwiatkowski D, Phillips PC, Schmidt P, Shin Y (1992) Testing the null hypothesis of stationarity against the alternative of a unit root: How sure are we that economic time series have a unit root? J Econ 54(1-3):159-178

Lam PL, Shiu A (2010) Economic growth, telecommunications development and productivity growth of the telecommunications sector: evidence around the world. Telecommun Policy 34(4):185-199

Lechman E, Marszk A (2015) ICT technologies and financial innovations: the case of exchange traded funds in Brazil, Japan, Mexico, South Korea and the United States. Technol Forecast Soc Chang 99:355-376 
Lee CC, Chang CP (2008) Tourism development and economic growth: a closer look at panels. Tour Manag 29(1):180-192

Lee CC, Chien MS (2008) Structural breaks, tourism development, and economic growth: Evidence from Taiwan. Math Comput Simul 77(4):358-368

Lehr B, Lichtenberg F (1999) Information technology and its impact on firm-level productivity: evidence from government and private data sources, 1977-1993. Can J Econ 32(2):335-362

Lorde T, Francis B, Drakes L (2011) Tourism services exports and economic growth in Barbados. Int Trade J 25(2):205-232

MacKinnon JG (1996) Numerical distribution functions for unit root and cointegration tests. J Appl Econ 11(6):601-618

Madden G, Savage SJ (1998) CEE telecommunications investment and economic growth. Inf Econ Policy 10(2):173-195

Martínez D, Rodríguez J, Torres JL (2010) ICT-specific technological change and productivity growth in the US: 1980-2004. Inf Econ Policy 22(2):121-129

Massidda C, Mattana P (2013) A SVECM analysis of the relationship between international tourism arrivals, GDP and Trade in Italy. J Travel Res 52(1):93-105

Nadiri MI, Nandi B (1999) Technical change, markup, divestiture, and productivity growth in the US telecommunications industry. Rev Econ Stat 81(3):488-498

Narayan PK (2005) The saving and investment nexus for China: evidence from cointegration tests. Appl Econ 37(17):1979-1990

Nayaran PK, Nayaran S, Prasad A, Prasad BC (2010) Tourism, and economic growth: a panel data analysis for Pacific Island countries. Tour Econ 16(1):169-183

Norton SW (1992) Transaction costs, telecommunications, and the microeconomics of macroeconomic growth. Econ Dev Cult Change 41(1):175-196

Nowak J-J, Sahli M, Cortés-Jiménez I (2007) Tourism, capital good imports and economic growth: theory and evidence for Spain. Tour Econ 13(4):515-536

Odhiambo NM (2009) Energy consumption and economic growth nexus in Tanzania: An ARDL bounds testing approach. Energy Policy 37(2):617-622

O'Mahony M, Vecchi M (2005) Quantifying the impact of ICT capital on output growth: a heterogeneous dynamic panel approach'. Economica 72(288):615-633

Oh CO (2005) The contribution of tourism development to economic growth in the Korean economy. Tour Manag 26(1):39-44

Oliner S, Sichel D (2000) The resurgence of growth in the late 1990s: is information technology the story? J Econ Perspect 14(4):3-22

Oulton N (2002) ICT and productivity growth in the UK. Oxford Rev Econ Policy 18(3):363-379

Oulton N (2012) Long term implications of the ICT revolution: applying the lessons of growth theory and growth accounting. Econ Model 29(5):1722-1736

Pelgrum WJ (2001) Obstacles to the integration of ICT in education: results from a worldwide educational assessment. Comput Educ 37(2):163-178

Perego A, Perotti S, Mangiaracina R (2011) ICT for logistics and freight transportation: a literature review and research agenda. Int J Phys Distrib Logist Manag 41(5):457-483

Pesaran MH, Timmermann A (2002) Market timing and return prediction under model instability. J Empirical Finance 9(5):495-510

Pesaran MH, Shin Y, Smith R (2001) Bounds testing approaches to the analysis of level relationships. J Appl Econ 16(3):289-326

Pohjola M (2002) The new economy in growth and development. Oxford Rev Econ Policy 18(3):380-396

Porter M (2001) Strategy and the internet. Harvard Bus Rev 79(3):62-78

Pradhan RP, Arvin MB, Norman NR, Bele SK (2014) Economic growth and the development of telecommunications infrastructure in the G-20 countries: a panel-VAR approach. Telecommun Policy 38(7):634-649

Pradhan RP, Arvin MB, Norman NR (2015) The dynamics of information and communications technologies infrastructure, economic growth, and financial development: evidence from Asian countries. Technol Soc 42:135-149

Pradhan RP, Arvin MB, Hall JH (2016) Economic growth, development of telecommunications infrastructure, and financial development in Asia, 1991-2012. Q Rev Econ Finance 59:25-38

Proença S, Soukiazis E (2008) Tourism as an alternative source of regional growth in Portugal: a panel data analysis at NUTS II and III levels. Port Econ J 7(1):43-61 
Rao BB (2010) Estimates of the steady state growth rates for selected Asian countries with an extended Solow model. Econ Model 27(1):46-53

Reynolds T, Samuels A (2004) Building digital bridges with emerging technologies. In: Digital bridges symposium, international telecommunication union, Seoul. http://www.itu.int/osg/spu/ni/ digitalbridges/docs/background/BDB-technology.pdf

Rohman IK, Bohlin E (2014) Decomposition analysis of the telecommunications sector in Indonesia: what does the cellular era shed light on? Telecommun Policy 38:248-263

Röller LH, Waverman L (2001) Telecommunications infrastructure and economic development: Asimultaneous approach. Am econ rev 91(4):909-923

Romer PM (1986) Increasing returns and long-run growth. J Polit Econ 94(5):1002-1037

Romer PM (1990) Endogenous technological change. J Polit Econ 98(5, Part 2):S71-S102

Sassi S, Goaied M (2013) Financial development, ICT diffusion and economic growth: lessons from MENA region. Telecommun Policy 37(4):252-261

Seetanah B (2011) Assessing the dynamic economic impact of tourism for island economies. Ann Tour Res 38(1):291-308

Seetanah B, Padachi K, Rojid S (2011) Tourism and economic growth: African evidence from panel vector autoregressive framework. Working Paper No. 2011/33, UNU-WIDER

Seo HJ, Lee YS, Oh JH (2009) Does ICT investment widen the growth gap? Telecommun Policy 33(8):422-431

Shahiduzzaman M, Alam K (2014) The long-run impact of information and communication technology on economic output: the case of Australia. Telecommun Policy 38(7):623-633

Shahiduzzaman M, Layton A, Alam K (2015) On the contribution of information and communication technology to productivity growth in Australia. Econ Change Restruct 48(3-4):281-304

Sheldon P (1997) Tourism information technologies. CAB, Oxford

Shih HY, Chang TLS (2009) International diffusion of embodied and disembodied technology: a network analysis approach. Technol Forecast Soc Chang 76(6):821-834

Singh S, Krakover S (2013) Homeland entitlement: perspectives of Israeli domestic tourists. J Travel Res 54(2):222-233

Solow RM (1956) A contribution to the theory of economic growth. Quart J Econ 70(1):65-94

Stauvermann PJ, Kumar RR, Shahzad SJH, Kumar NN (2016) Effect of tourism on economic growth of Sri Lanka: accounting for capital per worker, exchange rate and structural breaks. Econ Change Restruct. https://doi.org/10.1007/s10644-016-9198-6

Stiroh KJ (2002) Are spillovers driving the new economy? Rev Income Wealth 48(1):33-57

Strobel T (2016) ICT intermediates and productivity spillovers-Evidence from German and US manufacturing sectors. Struct Change Econ Dyn 37(C):147-163

Sturm J-R (1998) Public capital expenditure in OECD countries: the causes and impact of the decline of public capital spending. Edgar Elgar, Cheltenham

Tang CF, Tan EC (2015) Does tourism effectively stimulate Malaysia's economic growth? Tour Manag 46:158-163

Thompson HG, Garbacz C (2011) Economic impacts of mobile versus fixed broadband. Telecommun Policy 35(11):999-1009

Van Biesebroeck J (2003) Revisiting some productivity debates. NBER Working Paper 10065, NBER, Cambridge, MA

Venturini F (2009) The long-run impact of ICT. Empir Econ 37(3):497-515

Vu KM (2011) ICT as a source of economic growth in the information age: empirical evidence from the 1996-2005 period. Telecommun Policy 35(4):357-372

$\mathrm{Vu}$ KM (2013) Information and communication technology (ICT) and Singapore's economic growth. Inf Econ Policy 25(4):284-300

Ward MR, Zheng S (2016) Mobile telecommunications service and economic growth: evidence from China. Telecommun Policy 40:89-101

World Bank (2017) World development indicators and global development finance. Washington D.C, World Bank 